NBER WORKING PAPER SERIES

\title{
THE GREAT INFLATION IN THE UNITED STATES AND THE UNITED KINGDOM: RECONCILING POLICY DECISIONS AND DATA OUTCOMES
}

\author{
Riccardo DiCecio \\ Edward Nelson \\ Working Paper 14895 \\ http://www.nber.org/papers/w14895
NATIONAL BUREAU OF ECONOMIC RESEARCH
1050 Massachusetts Avenue
Cambridge, MA 02138
April 2009

An earlier version of this paper was presented at the NBER Great Inflation Conference, Woodstock, Vermont, September 25-27, 2008. We thank Frank Smets and Rafael Wouters for providing the estimation code for Smets and Wouters (2007). We are grateful to Michael Bordo and Athanasios Orphanides (the conference organizers), Matthew Shapiro (our discussant), and conference and pre-conference attendees, for comments on the previous versions of this paper. We are also indebted to Leon Berkelmans, Christopher Erceg, Jesper Lindé, Andrew Levin, Christopher Neely, Ricardo Nunes, Christina Romer, David Wheelock, and seminar participants at the Federal Reserve Board for many useful suggestions. Charles Gascon, Luke Shimek, and Faith Weller provided research assistance. The views expressed in this paper are those of the authors and should not be interpreted as those of the Federal Reserve Bank of St. Louis, the Federal Reserve System, the Board of Governors, or the National Bureau of Economic Research.

NBER working papers are circulated for discussion and comment purposes. They have not been peerreviewed or been subject to the review by the NBER Board of Directors that accompanies official NBER publications.

(C) 2009 by Riccardo DiCecio and Edward Nelson. All rights reserved. Short sections of text, not to exceed two paragraphs, may be quoted without explicit permission provided that full credit, including (C) notice, is given to the source. 
The Great Inflation in the United States and the United Kingdom: Reconciling Policy Decisions and Data Outcomes

Riccardo DiCecio and Edward Nelson

NBER Working Paper No. 14895

April 2009

JEL No. E31,E52,E58

\begin{abstract}
We argue that the Great Inflation experienced by both the United Kingdom and the United States in the 1970s has an explanation valid for both countries. The explanation does not appeal to common shocks or to exchange rate linkages, but to the common doctrine underlying the systematic monetary policy choices in each country. The nonmonetary approach to inflation control that was already influential in the United Kingdom came to be adopted by the United States during the 1970s. We document our position by examining official policymaking doctrine in the United Kingdom and the United States in the 1970s, and by considering results from a structural macroeconomic model estimated using U.K. data.
\end{abstract}

Riccardo DiCecio

Federal Reserve Bank of St. Louis

Research Division

P.O. Box 442

St. Louis, MO 63166-0442

Riccardo.DiCecio@stls.frb.org

Edward Nelson

Research Division

Federal Reserve Bank of St. Louis

P.O. Box 442

St. Louis, MO 63166

edward.nelson@stls.frb.org 


\section{Introduction}

In this paper we study the Great Inflation in both the United States and the United Kingdom. Our concentration on more than one country reflects our view that a sound explanation should account for the experience of the Great Inflation both in the United States and beyond. We emphasize further that an explanation for the Great Inflation should be consistent with both the data and what we know about the views that guided policymakers.

Figure 1 plots four-quarter inflation for the United Kingdom using the Retail Price Index, and four-quarter inflation using the U.S. CPI. The peaks in inflation in the mid-1970s and 1980 are over 20\% in the United Kingdom, far higher than the corresponding U.S. peaks. On the other hand, the ups and downs do resemble those in the United States; if we plotted the U.K. series alone and removed the numbering from the vertical axis, the figure might easily be mistaken at first glance for a depiction of U.S. inflation. This suggests that U.S. and U.K. inflation share a basic common explanation. But, for reasons discussed below, the most standard rationalizations for the coincidence of inflation across economies - those that emphasize trading and exchange rate linkages — are not very appealing when it comes to explaining the similarities in the U.S. and U.K. inflation experiences. Instead of appealing to common shocks or to exchange rate regime, we explain the similarity of U.S. and U.K. inflation by appealing to the common doctrines underlying policy decisions. In particular, the flawed approach to inflation analysis, which dominated U.K. policymaking for several postwar decades, became very influential in the United States in the 1970s.

In the course of our paper, we establish the following about the Great Inflation of the Seventies:

(1) Nonmonetary approaches to inflation analysis and control dominated pre-1979 policymaking in the United Kingdom.

(2) U.S. policymakers adopted this framework from the early 1970s, and so believed that inflation was a nonmonetary phenomenon, in a sense made precise below. This implied a belief that cost-push forces could produce inflation in the long run, even without monetary accommodation. 
Figure 1. U.K. and U.S. four-quarter inflation rates

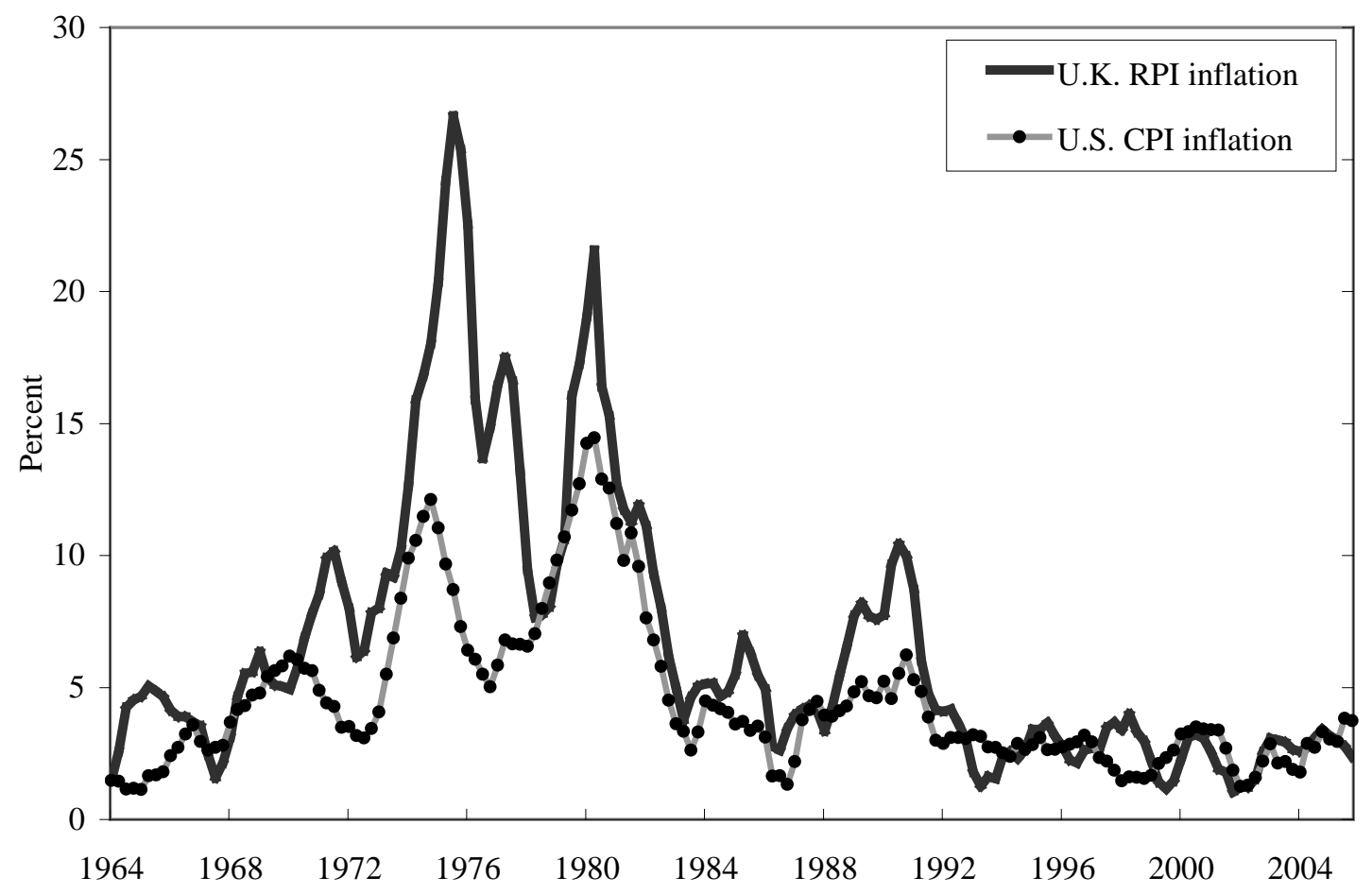

(3) The nonmonetary view of inflation was held consistently by Federal Reserve Chairman Arthur Burns from late 1970 until his departure in 1978, and adhered to by other senior policymakers during Burns' tenure and in 1978-79.

(4) As a corollary, 1970s inflation outcomes did not reflect policymakers' use of a Phillips curve model (with or without the "vertical in the long run" property).

We use "Great Inflation of the Seventies" rather than "Great Inflation” deliberately because our account stresses the influence of U.K. ideas on 1970-79 U.S. policymaking, and not on U.S. policy in both the 1960s and 1970s. For the United States, we do not find it useful to categorize the 1960s as part of the same inflation epoch as that of the 1970s. To do so is to gloss over the very significant segment of U.S. policymaking in 1969-70 in which both policy decisions and the principles guiding them were largely modern and appropriate (i.e.: natural rate/long-run-vertical Phillips curve ideas had been rapidly incorporated into policy thinking; and the monetary authorities deliberately made real interest rates positive in order to move from an excess aggregate demand position, to a zero or temporarily negative output gap, so as to remove inflationary pressure). The key to understanding 1970s policymaking in the United States is an appreciation of the 
fact that, instead of continuing the 1969-70 framework, U.S. policy thinking "went British," with cost-push ideas becoming dominant at the most senior policy levels from late 1970. As Milton Friedman (1979a) observed, "Ever since the founding of the colonies in the New World, Britain has been a major source of our economic and political thought.” The Great Inflation period is another example of this influence, as the predominant U.S. policy thinking during the 1970s was patterned on a U.K. precedent.

In Section 2 we discuss why we emphasize doctrine in studying the Great Inflation. Then in Sections 3 and 4 we document the common themes in U.K. and U.S. policymaking. We go on to illustrate in Section 5 some of our points about U.K. policymaking doctrine in the 1970s through an examination of the monetary policy shock realizations implied by a version of the Smets and Wouters (2007) model estimated on U.K. data. We also critically consider more benign interpretations of U.K. monetary policy decisions during the 1970s. Section 6 concludes.

\section{Why we emphasize doctrine}

With the benefit of hindsight, the discussions of the Great Inflation in such 1990s contributions as Taylor (1992), McCallum (1995), and DeLong (1997) can be seen as a backlash against the mechanical application of an "as-if" approach to analyzing past policy episodes. A common practice in studying U.S. inflation data had been to take for granted that policymakers knew the correct model of private economic behavior (i.e., the specification of IS and Phillips curves). Likewise, the "as-if" approach viewed data outcomes as the result of policymakers' optimization of their objective function, conditional on their correct specification of private behavior (which appeared as constraints in the policymaker optimization problem). Applications to the Great Inflation of the time-consistency or conservative-central-banker hypotheses can be thought of as quintessential examples of the "as-if" approach. These stories attribute to policymakers knowledge of the economy's structure, and characterizes high inflation as a conscious choice by policymakers-a choice following from their assumed preference for a positive output gap target.

The as-if assumption is not appropriate for the study of policymakers' choices, even though it is valuable for the modeling of choices by private agents. Recognition of this point has naturally been followed by the greater integration into the study of the Great Inflation of nonquantitative information, including the record of policymakers' stated 
views of the economy. Such an approach has been pursued by Romer and Romer (2002, 2004), Orphanides (2003), and others in the study of U.S. 1970s policymaking, and is continued in this paper. The emphasis that this approach gives to the importance of policymakers' views also brings the study of the Great Inflation onto the same footing as the study of other episodes in monetary history. For example, Romer and Romer (2004) observe that examination of the ideas driving policymaking was an important element of Friedman and Schwartz's (1963) study of the Great Depression, ${ }^{1}$ while the analysis of inflation targeting by Bernanke, Laubach, Mishkin, and Posen (1999) makes extensive use of policymakers' statements.

The emphasis on policymakers' misconceptions about economic behavior has further antecedents in the 1970s discussions of the Great Inflation in both the United States and the United Kingdom. Friedman (1972, p. 13) argued that "the erratic and destabilizing monetary policy has largely resulted from the acceptance of erroneous economic theories"; in that connection, Friedman attributed cost-push views regarding inflation to Federal Reserve Chairman Arthur Burns. In the United Kingdom, Robbins (1973) likewise blamed policy mistakes on cost-push views, which, he argued, meant that the United Kingdom was suffering from a "crisis of intellectual error... due largely to misconceptions prevalent even at high expert levels.” Laidler (1979, p. 899) similarly judged that the United Kingdom's inflation performance reflected the use of "erroneous economics" in policy formation.

It is one thing to attribute the policy decisions underlying the Great Inflation to policymakers' erroneous views about economic behavior; it is another to take a stand on the specific theoretical errors that were the main source of Great Inflation policies. Romer (2005) groups a number of candidate explanations for the Great Inflation under the umbrella of the "ideas hypothesis." The arguments made in the aforementioned studies by Taylor (1992), McCallum (1995), and DeLong (1997) all fall under that umbrella; specifically, all three studies conjecture that 1970s policymakers believed in a long-run Phillips curve tradeoff. While sharing these authors' rejection of the timeconsistency story, we reject their appeal to a tradeoff explanation. We believe that an important element of a good positive-economics explanation for the Great Inflation is recognition that inflation was not consciously created by policymakers. This is a much-

\footnotetext{
${ }^{1}$ Meltzer (2003) also traces Great Depression-era monetary policy decisions to Federal Reserve doctrine, which he argues was constant across the 1920s and 1930s.
} 
neglected feature of the Great Inflation. Any story of the Great Inflation that appeals either to time-consistency arguments or to monetary policy exploitation of a Phillips curve equation is, at its core, claiming that policymakers deliberately injected inflation into the economy. This claim flies in the face of the evidence that 1970s policymakers believed that inflation was not a monetary phenomenon. Policymakers in the 1970s had a modern view of the costs of inflation, but lacked a modern view of their power to determine the inflation rate through monetary policy. An approach that attempts to be realistic about the considerations driving 1970s monetary policy decisions must take this fact into account.

\subsection{Sources}

Gorodnichenko and Shapiro (2007, p. 1152) observe that the absence of electronic versions of Arthur Burns' public statements is an obstacle to a comprehensive analysis of the information in those statements. This observation is valid for the textual analysis that Gorodnichenko and Shapiro apply to statements, which requires the entirety of the statements (i.e., the population); it is also a legitimate concern if the aim is to discern Burns' model of the economy, as this again ideally involves studying the population of statements, and certainly requires a large and representative sample. Large samples of Burns' statements have been covered by the separate analyses of Burns' views on the economy in Romer and Romer (2002, 2004), Hetzel (1998), Christiano and Gust (2000), Orphanides (2003), and Nelson (2005), with much non-overlapping material across papers. One aim of the present paper is to reconcile our characterization of Burns' views with these studies. But in obtaining the characterization we give, we make use of a large sample of Burns' statements that includes many not cited in the earlier studies. One reason why we are able to undertake this is that there has been a major improvement in the electronic availability of Federal Reserve Chairmen's statements through the Federal Reserve Bank of St. Louis' FRASER archival database. This database contains speeches and opening statements to Congress made by Chairman Burns, including the substantial number not included in the selection in Burns (1978). At present the database does not include the question-and-answer portion of Congressional testimony, but we draw on these by consulting the relevant hardcopy transcripts.

In the United Kingdom, central bank independence did not exist prior to 1997. Monetary policy decisions were made by the Treasury, and so by the executive branch of the government. Nelson $(2005,2008)$ characterizes the economic doctrine of pre-1997 U.K. 
governments by collecting and reconciling public statements on economic matters given by leading policymakers. In this paper, on the other hand, we look at a source not previously consulted—namely, the U.K. Treasury’s Economic Progress Report, a monthly analysis of economic conditions that began publication in January 1970. In the following section, we set out the doctrine revealed by analysis of this policy publication.

\section{Official U.K. doctrine on inflation during the 1970s}

This section outlines the doctrine underlying policymaking in the United Kingdom during the 1970s. The documentation of U.K. Treasury views provided here shows that there were several aspects of U.K. official doctrine on inflation held consistently over 1970-79 (not all completely independent propositions, but listed separately for ease of our documentation below):

(i) Monetary policy can be a source of inflation, by producing excess aggregate demand.

(ii) Pure cost-push inflation (i.e., sustained inflation in the absence of excess demand) can occur.

(iii) It follows from (i) that monetary restraint (e.g., monetary policy designed to remove the excess of nominal spending growth over potential output growth in the long run) is a necessary element of inflation control.

(iv) But from (ii) above, monetary restraint is not sufficient for inflation control, even in the long run.

(v) There is a first-difference or speed-limit term driving inflation dynamics, irrespective of the sign of the output gap.

(vi) There is no long-run tradeoff between inflation and the output gap (or equivalently, no long-run tradeoff between inflation and unemployment relative to its natural rate).

We now document each of these points using the Treasury's Economic Progress Report $(E P R)$. 


\section{(i) Excess demand can add to inflation}

The U.K. Treasury recognized that "excess total demand" could be a source of inflation (EPR, July 1978, p. 4) and this was one reason "to avoid overheating the economy" (EPR, November 1977, p. 1).

\section{(ii) Inflation can be a purely cost-push phenomenon}

According to the Treasury, the postwar period in the U.K. had "led to a general realization that inflation could not be simply identified with excess total demand" (EPR, July 1978, p. 4). Its own analysis of inflation emphasized nonmonetary factors. For example, a 1968 Treasury analysis in the publication Economic Trends observed,

“The retail price index rose by about $1 / 2$ per cent in June... The increase in June was largely the result of higher prices for fresh fruit and the reintroduction of prescription charges, which were only partially offset by lower potato prices.” (Treasury, “The Economic Situation,” in Economic Trends, August 1968, p. vii.)

An analysis like this might be appropriate for analyzing erratic monthly movements in the price level, but the Treasury carried it over to the analysis of longer-term inflation movements. And when it came to explaining inflation movements at a deeper level than referring to movements in specific components of the price index, the Treasury was typically satisfied to appeal to the relation between prices and costs:

"The main factor sustaining this continuing high rate of price increase has been the rapid advance in wage costs...” (EPR, November 1970, p. 6.)

"The factors underlying the rise of prices have, however, changed. The initial acceleration was mainly a result of the effects of devaluation on import prices... Since last autumn, however, a different pattern has emerged... [T]here has been a very marked rise in costs resulting mainly from the fast rise in money wages..." (EPR, January 1971, p. 6.)

"A higher level of pay settlements was much the most important factor in the faster rise of costs and prices during 1970...” (EPR, May 1971, p. 5.) 
"The slow rise in the prices of basic materials and fuel in recent months has, however, been more than offset by the strong rate of increase in wage costs, which have become the dominant influence on price rises.” ( $E P R$, June 1975, p. 6.)

The prevalence of cost-push explanations for inflation at the official level across the 1970s indicates that exogenous cost shocks were not being invoked simply to account for short-run movements in inflation, but for ongoing movements too. This reflected the U.K. Treasury's uncritical acceptance of the notion that "the phenomenon of persistent inflation reflected a cost-push_and specifically wage-push—progress, associated with modern collective bargaining procedures.” (EPR, July 1978 p. 4.)

\section{(iii) Monetary restraint is a necessary element of inflation control}

The Treasury did accept that monetary restraint could contribute to avoiding inflation that arose from positive output gaps. Consequently, it referred to 1977 policy developments with the observation, "Firm control of the main monetary aggregates continued to be an important feature of policy...” (EPR, April 1978, p. 5.)

\section{(iv) Monetary restraint is not sufficient for inflation control}

But the U.K. authorities thought that a negative output gap did not remove inflationary pressure. Persistent inflation alongside negative output gaps-which U.K. policymakers thought was the state of affairs prevailing during most of the 1970s - therefore appeared to justify the use of nonmonetary instruments against inflation. The Treasury credited incomes policy with lowering inflation: "Current pay policy appears to have been successful in avoiding an inflationary 'pay explosion.'” (EPR, April 1978, p. 5.)

\section{(v) There is a speed-limit term driving inflation dynamics}

The U.K. Treasury did concede a role for demand in determining inflation when the output gap was negative, but this concession was limited to an influence of the change in the output gap on inflation (not of the gap level, as in Phillips curve analysis). For example, in 1967 the Treasury observed, 
"If over any period the projected rate of increase in output is faster than that of potential output, the pressure of demand will rise and this is normally likely to result in a feedback through the economy on the rate of increase of wage rates..." (Treasury, “Econometric Research for Short-Term Forecasting,” Economic Trends, February 1967; quotation from p. x; emphasis added.)

In the 1970s, the Treasury again allowed a gap-growth-rate term as a possible influence on inflation:

"The index of retail prices has shown a much smaller monthly increase recently... reflecting some slowing down in the growth of domestic costs and possibly the falling pressure of demand.” (EPR, November 1975, p. 7.)

The Treasury thus saw only a deteriorating output gap, not a constant negative output gap level, as capable of taking away inflationary pressure.

\section{(vi) There is no long-run tradeoff between inflation and the output gap}

The U.K. Treasury did not embrace the tradeoff view of inflation associated with a permanently negatively sloped Phillips curve. ${ }^{2}$ It viewed the whole postwar period as witnessing "persistence of inflation even during the downturn and 'trough' phases of the business cycle” (EPR, July 1978, p. 4), thereby defying simple Phillips curve analysis. This did not lead the Treasury to adopt modern expectational Phillips curve analysis before the late 1970s, but did lead it to reject the view that eliminating inflation and restoring a zero output gap (from its perceived negative value) were incompatible goals. Thus in 1975, the Treasury observed, "A sharp reduction in the rate of inflation is now an overriding priority for the nation and a precondition for a reduction of unemployment..." (EPR, August 1975, p. 1.) It later added, "Failure to control inflation will put all these objectives at risk.” (EPR, July 1976, p. 3.)

\subsection{The change in official doctrine (1979)}

In 1979, following the election of the Thatcher Government, the Treasury noted that the introduction of new macroeconomic policies "represent a complete change of attitude

\footnotetext{
${ }^{2}$ To be precise, here we mean a curve that is negatively sloped when a scatter of unemployment and inflation is considered.
} 
towards the way in which the economy works...” (EPR, June 1979, p. 1); in particular, inflation was now accepted as being a monetary phenomenon, and incomes policies were abandoned. Consistent with this framework, the Treasury attributed the decline in inflation in 1982 to “a low pressure of demand” (EPR, November 1982, p. 10). Its perspective on the pressure of demand that had prevailed during the 1970s changed too; the Treasury observed that the "underlying growth in productivity in most countries seems to have fallen since the early 1970s” (EPR, October 1979, p. 1), and, in parallel with U.S. developments described in Orphanides (2003), the U.K. authorities revised down their estimates of potential output for the 1970s. ${ }^{3}$ With more realistic estimates of potential output, previous output/inflation combinations were more compatible with a monetary explanation for inflation.

\subsection{International factors: Bretton Woods}

Where does Bretton Woods fit into the U.K. experience? Cecchetti et al(2007) note that the Great Inflation outside the United States is often routinely explained by appealing to the transmission of U.S. inflation via the Bretton Woods mechanism. The breakdown of Bretton Woods is also often similarly cited as a source of world inflation. Some studies of the United Kingdom, such as Benati (2004), do use Bretton Woods as a means of classifying different U.K. monetary policy regimes. ${ }^{4}$ Here we explain why we emphasize flaws in domestic policy thinking rather than the changing status of Bretton Woods as the source of the United Kingdom’s Great Inflation.

The United Kingdom had a fixed exchange rate until June 1972, with no changes in its dollar exchange value between 1967 and 1971. It would nevertheless be inappropriate to conclude that Bretton Woods was a constraint whose disappearance produced the U.K.'s Great Inflation, and whose pre-1972 presence prevented U.K. economic doctrines from determining U.K. monetary policy. On the contrary, extensive foreign exchange controls gave U.K. policymakers substantial scope to vary domestic interest rates for reasons other than the exchange rate constraint.

\footnotetext{
${ }^{3}$ See Nelson and Nikolov (2004) for details on output gap mismeasurement in the United Kingdom during the 1970s, and the subsequent official revisions.

${ }^{4}$ For other recent discussions of whether Bretton Woods was responsible for the spread of the Great Inflation, see Bordo and Eichengreen (2008) and Romer (2005).
} 
It is difficult to pinpoint an instance where the fixed exchange rate policy in itself dictated a tighter monetary policy in the United Kingdom in the 1960s and 1970s. A policy tightening in 1966 did coincide with a foreign exchange crisis, but also coincided with a perceived positive output gap, which in its own right would justify a tightening. When a foreign exchange crisis in 1967 coincided with a perceived negative output gap, devaluation was permitted; for the rest of the 1960s, the balance-of-payments constraint was perceived as a restriction on the allocation of output across sectors rather than on demand in aggregate. And there was no conflict between exchange rate policy and demand management in 1970-71: interest rates were cut, and never raised, in both years; this monetary expansion was desired by the authorities for domestic reasons; and the balance of payments surpluses that occurred were consistent with the aim of stimulating the U.K. economy. When a conflict between the U.K. authorities' expansion of demand and their exchange rate obligations did arise in 1972, the conflict was resolved not by imposition of the external constraint on monetary policy decisions, but by floating of the pound sterling.

\subsection{International factors: the influence of overseas experience}

As the preceding discussion implies, we assign little importance to structural economic forces, as opposed to common policymaking doctrine, in accounting for similarities in inflation rates across countries during the 1970s. This assignment, as well as our emphasis on the United Kingdom as the originator of doctrine, matches up with an assessment made on one occasion by Milton Friedman (1979b, pp. 35-36):

"I do not believe there is any such thing as world inflation; there is only inflation in individual nations. Given a floating exchange rate system, there need be no relationship between the inflation [rate] in one country and another... [T]here is a common element, namely the force of ideas... Countries all over the world are experiencing inflation because countries all over the world have been affected by the socialist and Keynesian sets of ideas that have emanated very largely from Great Britain...”

But this account has so far left unanswered the question of why U.K. policymakers were guided by an erroneous doctrine for so long. If, as we argue, U.K. policymakers were mistaken in regarding inflation as a cost-push phenomenon, why did they not realize their error earlier? In particular, why didn't low inflation in countries like Germany make 
U.K. policymakers wake up to the need to use monetary policy as the central weapon against inflation, and to abandon their reliance on price and wage control measures? ${ }^{5}$

The answer is that U.K. policymakers and many leading U.K. commentators rationalized other countries' experiences in two ways. The first rationalization was the position that inflation in other countries may well reflect excess demand problems in those countries, but that the U.K. inflation actually was a cost-push problem. For example, a 1970 news report of a bulletin by the U.K.'s influential National Institute of Economic and Social Research said, "In most other European countries, it is argued, inflation is caused by increasing consumer demands. In Britain, by contrast, inflation appears to be the result of the sharp rises in wages..."6 The second rationalization attributed low inflation in Germany to nonmonetary factors, such as the incomes policies allegedly implied by Germany’s “social market” framework.

Prominent outside observers of the U.K. economy often accepted or reinforced the view that U.K. inflation was cost-push in nature. For example, Solow (1969, p. 24) stated, "The conventional view is that the price level is almost completely cost-determined in Great Britain, and is certainly less sensitive to direct demand conditions than in the United States. My results generally confirm this view.” In 1970, the OECD Secretary General, Emile van Lennep, said, “Inflation has been accelerating in the United Kingdom despite the fact that demand pressure has been falling for several years." ${ }^{7}$ Later, Blinder (1979, p. 74) observed, "From what I have heard about the U.K. economy, not even the most dedicated data miner can detect an effect of demand on inflation.” Blinder added that it "may indeed be empirically valid" to treat unemployment as exerting no influence on U.K. wage determination (1979, p. 75).

\subsection{Summing up 1970s doctrine}

Our characterization of U.K. policymakers' views of inflation can be summarized by a modified Phillips curve such as: ${ }^{8}$

\footnotetext{
${ }^{5}$ Beyer et al (2009) provide further comparison of German and U.K. monetary policies during the 1970s. ${ }^{6}$ Kansas City Star, August 26, 1970.

${ }^{7}$ Quoted in Daily Telegraph (London), November 11, 1970.

${ }^{8}$ Nelson (2008) justifies this equation on the basis of a different set of U.K. policymaker statements from that used here. The representation is also similar to the equation that Friedman and Schwartz (1982) use to characterize cost-push views of inflation.
} 
$\pi_{t}=b+\alpha D_{t}\left(y_{t}-y_{t}^{*}\right)+\delta \Delta\left(y_{t}-y_{t}^{*}\right)+\mathrm{E}_{t} \pi_{t+1}+\xi_{t}$.

Here $\pi_{t}$ is quarterly inflation, $b$ is a constant, $y_{t}-y_{t}{ }^{*}$ is the output gap (i.e., the log of the ratio of output to potential output), $\Delta$ is the first-difference operator, and $\xi_{t}$ is a cost-push process that is highly persistent and undergoes shifts in mean. The parameters $\alpha$ and $\delta$ are strictly positive, while $D_{t}$ is an indicator function that depends on the sign of the output gap: $D_{t}=1.0$ for $y_{t}>y_{t}{ }^{*}$, but $D_{t}=0$ for $y_{t}<y_{t}{ }^{*}$. The presence of this term implies that if equation (1) is a valid description of inflation behavior, the output gap level matters for inflation only when there is positive excess aggregate demand; excess supply (i.e., a negative output gap) fails to withdraw inflationary pressure. We will find that equation (1) is not in fact a valid description of inflation determination in the United Kingdom, and that the post-1979 policymakers were therefore correct to reject it. Nevertheless, U.K. policymakers' adherence to a view of inflation captured by equation (1) takes us far in understanding U.K. policy decisions during the 1970s. We take this point up in Section 5. Prior to that, we demonstrate that the mistaken views about inflation that were prevalent in the United Kingdom did not remain a source of error special to U.K. policy circles. On the contrary, these views were adopted during the 1970s by the principal policymakers in the United States.

\section{Official U.S. doctrine on inflation during the 1970s}

As we discuss in detail in Appendix A, in 1969-70 U.S. policymakers had fairly orthodox views of inflation, most notably expressed in their endorsement of a modern Phillips curve-i.e., policymakers believed that inflation was elastic with respect to demand pressure in all regions, and that the Phillips curve became vertical in the long run. This position appears to have been that of Arthur Burns upon becoming Federal Reserve Chairman in early 1970, and similar views were held by several key Nixon Administration personnel. But both Burns and other senior policymakers rapidly changed their view of the inflation process in favor of a predominantly nonmonetary approach. ${ }^{9}$ We contend that Burns' views throughout the period from late 1970 to his departure as Chairman in early 1978, as well as those of other major officials in 1970-78

\footnotetext{
${ }^{9}$ Romer and Romer (2002) contend that Burns entered office already holding cost-push views of inflation. For the contrary argument that Burns underwent a change shortly after taking office, see Nelson (2005). There is no disagreement across these accounts on the importance of nonmonetary views in Burns' thinking from late 1970 to late 1973, and both sources provide considerable documentation. Accordingly, our documentation here focuses on the more contentious and less documented issue of what were Burns' views from 1974 to 1978.
} 
and into 1979, are well captured by equation (1) and the accompanying propositions (i)(vi) given above. As we will see, Burns and other Federal Reserve Board figures explicitly appealed to the U.K. experience as a forerunner of the U.S. experience. Let us review the doctrinal items (i)-(vi) of Section 3 once more, this time using them to describe U.S. doctrine.

\section{(i) Excess demand can add to inflation}

Chairman Burns accepted that "policies that create excess aggregate demand... lead ultimately to galloping inflation” (July 30, 1974, testimony to Banking and Currency Committee, House of Representations, in Burns, 1978, p. 170). Accordingly, for inflation arising from excess demand, "the raging fires of inflation will eventually burn themselves out” if the boom was wound back by official restriction of demand (Burns, August 6, 1974, p. 17). ${ }^{10}$ Burns accepted that excess demand conditions had been created in the late 1960s and in 1973; accordingly, the "current inflation began in the middle 1960s" (August 21, 1974, p. 6) with "the underlying inflationary trend caused by lax financial policies” (July 27, 1976, p. 671), while 1973 had again seen an "overheating of the economy" (September 20, 1974, p. 4). More generally, Burns observed that "we also know that when the money supply grows excessively, inflation will be generated." (July 26, 1977, testimony, in Banking, Finance and Urban Affairs Committee, House of Representatives, 1977a, p. 99.) This proposition, he noted, was especially relevant to the medium term: "excessive monetary growth will eventually result in more rapid inflation" (September 25, 1975, testimony, in Budget Committee, U.S. Senate, 1975b, p. 177); and therefore: "If we create money at a more rapid rate than we have been doing, sooner or later that money will go to work and express itself in higher prices.” (July 29, 1975, testimony, in Joint Economic Committee, 1975, p. 158.)

Burns’ successor as Federal Reserve Chairman, G. William Miller, shared this perspective, contending, "If the Fed takes the restraint off and lets the money be printed, then, sure, there could be lower interest rates for a while, but then there would be a terrible inflation-and disaster."11

\footnotetext{
${ }^{10}$ References given in the text with a date and page number but no other bibliographical information are from Chairman Burns' statements and speeches as given in the Federal Reserve Bulletin or in the Federal Reserve Bank of St. Louis’ FRASER archive of Burns’ public statements (available at http://fraser.stlouisfed.org/historicaldocs/statements/). Bibliographical information on these statements is given chronologically in the Bibliographical Appendix.

${ }^{11}$ Quoted in the New York Times, July 4, 1978.
} 


\section{(ii) Inflation can be a purely cost-push phenomenon}

Federal Reserve officials during the 1970s also believed, however, that exogenous costpush forces (the $\xi_{t}$ term in equation (1)) could produce sustained inflation without monetary accommodation. The experience of the United Kingdom was invoked as an empirical example of this phenomenon. For example, an unsigned article in the Federal Reserve Bulletin of October 1970 stated,

“The United Kingdom provides the clearest example among the industrialized countries of inflation that is primarily of the cost-push variety. The British economy is clearly operating below its productive potential... Yet labor costs have been rising rapidly...” (Board of Governors, 1970, p. 749.)

Around this time, Chairman Burns came to the view that the U.S. economy had inherited the cost-push characteristics perceived as relevant to the United Kingdom. By mid-1975, when asked if he expected wages to respond to fundamentals, Burns was saying, "I hope you're right about the behavior of wages. That's the way things should work, but they haven't worked that way in recent years in this country or in Canada or in Great Britain.” (May 1, 1975, testimony. in Banking, Housing and Urban Affairs Committee, U.S. Senate, 1975, p. 194.)

Burns cited wage-push as a major source of inflationary pressure: "I do think that our trade unions at the present time have excessive market power. I also think that some of our legislation has been conducive to increases in wages and, therefore, to higher inflation rates...” (September 4, 1975, testimony, in Agriculture and Forestry Committee, U.S. Senate, 1975, p. 16.) Thanks to labor union behavior, wage-push pressures would exist even in the absence of wage-increasing legislation: "inflation has not come to an end... One of the most important sources it is coming from and will continue to come from is the increase in wages.” (July 29, 1975, testimony, in Joint Economic Committee, 1975, p. 152.) In 1977 Burns claimed: “in the last analysis the wage increases that take place are fundamental to the rate of inflation.” (November 9, 1977, testimony, in Banking, Housing and Urban Affairs Committee, U.S. Senate, 1977, p. 30.)

But Burns also cited firms as originators of cost-push pressure: "my impression is that many of our business corporations are no longer paying attention to factors on the 
demand side in the same way they did in earlier years.” (October 2, 1975, testimony, in Budget Committee, House of Representatives, 1975, p. 78.) Prices in particular sectors were also autonomous contributors to inflation, a key example being food prices: "concern about the effects of rising food prices on the overall rate of inflation is clearly warranted.” (September 4, 1975, testimony, in Agriculture and Forestry Committee, U.S. Senate, 1975, p. 3.) Burns had a parallel concern about import prices: "If the dollar depreciates in foreign exchange markets, that releases forces that tend to raise our price level.” (July 26, 1977, testimony. in Banking, Finance and Urban Affairs Committee, House of Representatives, 1977a, p. 70.) Any of these factors could aggravate domestic cost-push forces, Burns argued: "Nowadays, inflation from almost any source tends to be built into wages and thus to aggravate the wage-price spiral.” (September 4, 1975, testimony, in Agriculture and Forestry Committee, U.S. Senate, 1975, p. 4.) He summed up: "inflation has become, as you correctly point out, a complex phenomenon. I deplore some of the price increases that are taking place... I think, sometimes, that we are moving into a cost-plus economy, and that is a disturbing development." (September 25, 1975, testimony, in Budget Committee, U.S. Senate, 1975b, p. 168.) The great importance Burns attributed to cost-push factors came out in August 1974 when he stated that only about 3 to 3.5 percentage points of the United States' annual rate of inflation of $12 \%$ in the first half of 1974 could be attributed to money growth (August 21, 1974, testimony, in Committee on the Budget, U.S. Senate, 1974, p. 238).

Burns' cost-push views were so entrenched that they obscured his interpretation of the Fisher relation between expected inflation and nominal interest rates. He did recognize that the Fisher relation was fundamental: "Over the long run, the rate of inflation is the dominant influence on interest rates.” (September 25, 1975, testimony. in Budget Committee, U.S. Senate, 1975b, p. 166.) But since Burns believed that the wage-price controls introduced in August 1971 had directly reduced inflationary expectations, he felt that nominal interest rates could fall without implying a loosening of monetary policy. In a speech in November 1971, Burns said that "the freeze has been extremely effective," adding: "Interest rates have come down substantially as the inflationary premium has been squeezed out.” (November 11, 1971, p. 2.) This viewpoint allowed Burns to interpret cuts in interest rates by the Federal Reserve not as force-fed monetary stimulation, but as responses to falling private inflationary expectations: "Interest rates are still falling, and yesterday's decline in the Federal Reserve discount rate recognizes that.” (November 11, 1971, p. 3.) 
(iii) Monetary policy is a necessary part of inflation control

Burns accepted quantity-theory logic in the sense that he realized that the Federal Reserve could be a dominant influence on nominal spending growth $(\Delta m+\Delta v)$ over longer periods. He accordingly accepted that a necessary condition for price stability was for the Federal Reserve to provide nominal income growth rates that were not persistently excessive relative to long-run growth in potential output $\left(\Delta y^{*}\right)$. Thus he observed in 1975 that existing monetary growth rates, "while appropriate in the present environment, could not be maintained indefinitely without running a serious risk of releasing new inflationary pressures.” (May 1, 1975, testimony, in Banking, Housing and Urban Affairs Committee, U.S. Senate, 1975, p. 172.) Burns saw the Federal Reserve as concerned with "bringing the long-run growth of the monetary aggregates down to rates compatible with general price stability.” (July 29, 1977, testimony, in Banking, Finance and Urban Affairs Committee, House of Representatives, 1977b, p. 68.) Likewise, a downward money growth path was “absolutely necessary if President Carter's publicly announced goal of reducing the pace of inflation by two percentage points by the end of 1979 is to be achieved.” (May 3, 1977, p. 467; emphasis added.) We italicize "necessary” because its use instead of "necessary and sufficient” distinguishes Burns' nonmonetary view of inflation from the standard, monetary view. Monetary policy, in Burns' conception, was a necessary instrument for securing price stability because monetary policy actions were required to prevent the emergence of positive output gaps. Thus, when an excessdemand problem was perceived as having emerged in 1973, Burns observed that "classical tools of economic stabilization — that is, general monetary and fiscal policiescan be more helpful at such a time” (February 26, 1974, statement, in Joint Economic Committee, 1974 , p. 720$).^{12}$

\section{(iv) Monetary policy is not sufficient for inflation control}

Burns believed that monetary policy was not sufficient for inflation control. To cast the issue in quantity-equation terms, for $\Delta m+\Delta v$ to secure dependable control of inflation $(\pi)$, inflation should be endogenous and continuously related to aggregate demand. In those circumstances, actions on $\Delta m+\Delta v$ ultimately bear down on $\pi$ alone, leaving $\Delta y$ to

\footnotetext{
${ }^{12}$ Burns therefore recognized, in line with equation (1), that excess demand pressure could be superimposed on cost-push factors as a source of inflation, and acknowledged that an excess demand problem had emerged in 1973. Burns’ 1974 statements on the need for demand restraint thus do not constitute a repudiation of his cost-push views of inflation (though for a contrary interpretation, see Romer and Romer, 2004, p. 141).
} 
be pinned down by the exogenous value of potential output growth $\Delta y^{*}$. This was not, however, Burns' position; rather he saw $\pi$ as insensitive to aggregate demand over a large range, as it is in equation (1), implying that aggregate demand control cannot by itself secure inflation control.

In the following exchange Burns explicitly denied that one could speak of a specific noninflationary growth rate of money, or equivalently, a specific monetary policy that could deliver price stability:

Mr. NEAL. ... [W] hat would have happened had the money growth rate been consistent with price stability?

Dr. BURNS. I don't know that I or anyone else could ever answer that question, because we would be dealing with an imaginative reconstruction of the past. In any such reconstruction of the past, you would certainly have to specify the character of fiscal policy in the country. You would have to specify the labor policies pursued by the Government and by the trade unions and by business firms. You would have to specify pricing policies. Then you might get some approach to a meaningful answer... But I don't think you would learn a thing merely by asking what would have happened if monetary policy had kept the rate of growth of the money supply at a level that is consistent with general price stability. (July 27, 1976 question and answer session, in Banking, Currency and Housing Committee, House of Representatives, 1976, p. 28.)

Reflecting his judgment that monetary policy actions were insufficient for inflation control, Burns believed that incomes policy was needed, a position he repeated emphatically even after the abolition of wage-price controls in April 1974. For example, in August 1974, Burns said that "monetary policy should not be relied upon exclusively" and called for "[f]resh efforts" at incomes policy arrangements (August 6, 1974, pp. 17, 18). In 1975, Burns argued, "Sooner or later, in my judgment, we will move once again toward an incomes policy in this country... I think the world will continue to look in this direction for part of an answer to its problems." (July 29, 1975, testimony, in Joint Economic Committee, 1975, p. 145.) In the same year Burns offered a specific proposal: "I think we ought to hold up for public airing those instances where we have some reason to believe that there is an abuse of economic power, whether on the part of our 
corporations or our trade unions...” (October 2, 1975, testimony, in Budget Committee, House of Representatives, 1975, p. 179.)

Burns reaffirmed these positions in 1976 and 1977. In 1976, he observed, "In the kind of world that we live in-with trade unions playing a large role in the determination of wages, so that competition in the labor market is very limited, and with not a few of our business firms having market power, as I think we all know-if we try to rely solely on monetary and fiscal policies to achieve general price stability, I believe we are likely to fail... I am convinced that we will return to an incomes policy sooner or later...” (March 22, 1976, testimony, in Budget Committee, U.S. Senate, 1976, p. 85.) In 1977 Burns stated, "I feel, Senator, that some sort of incomes policy will have to be developed in our country...” (November 9, 1977, testimony, in Banking, Housing and Urban Affairs Committee, U.S. Senate, 1977, p. 29.)

Relative to an earlier period in U.S. history when aggregate demand management was a sufficient tool against inflation, Burns said, structural change had produced a "catch"; there were now "tremendous nonmonetary pressures...tending to drive costs and prices higher.” (August 13, 1977 speech, in Burns, 1978, p. 417.) A favorite formulation of Burns was that monetary policy in the new circumstances should do what it can against inflation, but that monetary policy was not enough. For example, Burns said in 1975: "The Federal Reserve is firmly committed to do what it can to restore general price stability in this country.” (May 1, 1975, testimony, in Banking, Housing and Urban Affairs Committee, U.S. Senate, 1975, p. 173; emphasis added.) He stressed in 1976: “Monetary policy alone, however, cannot solve our nation's stubborn problem of inflation.” (November 18, 1976, speech, in Burns, 1978, p. 250.) Even at his final FOMC meeting (in February 1978), which he presided over on an interim basis, Burns described himself and his colleagues as “do[ing] what we can to reduce the rate of inflation” (FOMC Minutes, February 28, 1978, p. 31). G. William Miller adopted similar formulations during his tenure as Federal Reserve Chairman (see e.g., Nelson, 2005).

Monetary policy within this framework was seen as able to provide a floor but not a ceiling for the inflation rate. As Burns put it, "if a 5 per cent rate of price advance were to be accepted complacently by Government, inflationary expectations would intensify, and the actual rate of price increases would then almost certainly move toward higher levels.” (February 3, 1977, p. 123.) 
Policymakers (erroneously) saw the predominant situation of the 1970s as one of coexisting cost-push inflation and negative output gaps. Therefore, the perceived function of monetary policy became one of avoiding a compounding of the cost-push inflation that would occur if a positive output gap (and accompanying demand-pull inflation) were permitted. Thus Burns described his money growth target choices in 1975-76 as designed to "facilitate substantial recovery in economic activity without aggravating the problem of inflation.” (July 27, 1976, p. 671.) Similarly, the following year he said that the "basic objective of monetary policy in the recent past has been to promote conditions conducive to substantial expansion in economic activity, while guarding against the release of new inflationary forces.” (March 2, 1977, p. 229.) “New" here refers to demand-pull forces on top of the existing cost-push forces. Or as Treasury Secretary Michael Blumenthal characterized the policy assignment in 1978, "Bill Miller has to keep the money supply from going through the roof."13

Burns summed up his necessary-but-not-sufficient vision of monetary policy in 1976: "Monetary policy—no matter how well designed and implemented — cannot do the job alone. Adherence to a moderate course of monetary policy can, however, make a significant contribution to the fight against inflation.” (July 27, 1976, p. 671.)

The series of papers of which this paper is part provides a detailed chronology of the nonmonetary actions against inflation taken in both the United Kingdom and the United States during the 1970s. In particular, Nelson (2005) discusses not only the U.S. wageprice controls of 1971-74, but later U.S. measures, including the Ford Administration’s "Whip Inflation Now" program of 1974, the Carter measures against specific prices in 1977, and the Carter Administration's incomes policy initiatives in 1978-79. It is true that use of incomes policies in the United States was not restricted to the 1970s, as wageprice guideposts were pursued by the Kennedy and Johnson Administrations in the 1960s. But the underlying theoretical rationale for the 1960s measures was distinct from the pure cost-push view of inflation that prevailed among U.S. policymakers in the 1970s. We discuss U.S. policies against inflation during the 1960s in Appendix A.

\section{(v) The growth rate of the output gap matters for inflation}

Burns took as a lesson from his studies of the business cycle that the first difference of

${ }^{13}$ Quoted in New York Times, July 4, 1978. 
the output gap mattered for inflation. Burns (1951, p. 198) observed, "inflation does not wait for full employment," and this belief carried over into his observations on 1970s developments. For example, in 1976, Burns argued, "Some step-up in the rate of inflation was perhaps unavoidable in view of the vigor of economic recovery.” (February 19, 1976, p. 233.) Later in the year he warned that underlying inflation "could well increase as our economy returns to higher level of resource utilization.” (November 18, 1976, speech, in Burns, 1978, pp. 244-245.) Likewise, in 1977 Burns stated: “As we should know by now, pressures on resources and prices can arise even at a time of substantial unemployment.” (February 23, 1977, p. 226.) He dismissed a negative output gap level as a restraint on inflation and emphasized instead the speed-limit channel: "Substantial amounts of idle capacity and manpower provide little assurance that price pressures will not mount as the economic growth rate speeds up. Indeed, the historical record of business cycles in our country clearly demonstrates... that the prices of final goods and services gather substantial upward momentum well before full utilization of resources is achieved....” (March 22, 1977, p. 361.)

In Burns' view, the first-difference term mattered for inflation in a symmetric manner: not only, as noted above, did he believe that very rapid expansion promoted inflation, but additionally, slow growth in output (relative to potential) restrained inflation (e.g., February 3, 1976, p. 5). This first-difference term could however be overwhelmed by the other factors mattering for inflation, so cost-push forces could raise inflation even during periods of a widening output gap (see his July 30, 1974, remarks on 1970-71 developments, in Burns, 1978, p. 170). Likewise, weakening cost-push forces could mean that inflation fell during a strong recovery, as in 1975-76.

The speed-limit element in Burns' view of inflation helps reconcile his endorsement of cost-push interpretations with other, seemingly more standard, Burns statements emphasized in other studies. Romer and Romer (2004, p. 141) interpret Burns' warnings of inflationary pressure in 1977 as reflecting "changes in [his] beliefs in the mid-1970s" toward believing that inflation responded to the level of slack as well as an assessment on Burns' part that output was exceeding potential, though they admit that they cannot reconcile the easy monetary policy of 1976-77 with this change of beliefs. No inference of change in Burns' views is necessary, however; policy statements by Burns throughout 1974-78 are consistent with the cost-push plus speed-limit views that we believe he held consistently over the 1970-78 period. 
Moreover, further examination suggests that Burns did not believe that the output gap was positive in 1977; the 1977 quotation Romer and Romer offer from Burns refers to "the pace of economic activity," i.e., a speed-limit not a gap-level channel from demand to inflation; and in the above quotations Burns explicitly referred to a level of economic slack existing in 1977, i.e., to a negative output gap. Indeed, Burns' statement that 'there is now considerable slack in the economy" (February 23, 1977, p. 226) and his observation of "[s]ubstantial amounts of idle capacity and manpower" (March 22, 1977, p. 361) specifically refute Romer and Romer's contention that Burns believed that the gap had turned positive by 1977. In addition, Burns' views on potential output had not adjusted downward adequately in 1977, as he endorsed a potential output growth rate estimate of "3.5 percent or a shade below that." (May 2, 1977, testimony, in Banking, Housing and Urban Affairs Committee, U.S. Senate, 1977, p. 17.)

Burns' speed-limit view can also reconcile his many statements about the limited power of monetary policy with his occasional observations that the Fed could, in fact, eliminate inflation. For example, Burns said in 1974, "we could stop this inflation in a very few months, and stop it dead in its tracks...” (February 26, 1974, testimony, in Joint Economic Committee, 1974, p. 747). In 1977, he stated, "For our part, we at the Federal Reserve know that inflation ultimately cannot proceed without monetary nourishment." (July 29, 1977, testimony, in Banking, Finance and Urban Affairs Committee, House of Representatives, 1977b, p. 69.) And similarly, he observed, "serious inflation could not long proceed without monetary nourishment” (in his August 13, 1977 speech, in Burns, 1978, p. 417.)

As discussed below, statements like these are often interpreted as implying that Burns really had a monetary view of inflation, according to which monetary accommodation is crucial in making cost-push shocks matter for inflation. This interpretation is untenable, as it contradicts Burns' many denials (including during 1974-78) that a specific inflation rate was implied by a particular monetary policy choice. But we can reconcile Burns' statements in the preceding paragraph with these denials by using equation (1), which represents our characterization of U.S. official doctrine in the 1970s. With equation (1), it is possible, starting from conditions of a zero or negative output gap, for a monetary policy to offset cost-push forces by making the output gap more negative.

Such a monetary policy effect on inflation has different characteristics from those that arise in a standard framework for describing inflation determination. According to the 
latter, a given negative output gap exerts ongoing downward pressure on inflation, and no alternative policy can remove inflation. But equation (1), in which negative levels of the output gap do not matter for inflation, implies that a given degree of aggregate demand restraint would exert only a temporary effect on inflation; a widening output gap (i.e., continuous negative growth in the output gap) is required to maintain downward pressure on inflation. Moreover, since cost-push forces are an independent source of ongoing inflation under specification (1), that specification suggests that it is valuable to remove these forces directly through nonmonetary measures.

Thus, Burns argued, the Fed could stop inflation via a restriction channel, but "the only way we could do that is to bring the distress of mass unemployment on this nation." (February 26, 1974, testimony, in Joint Economic Committee, 1974, p. 747.) Similarly, CEA Chairman Charles Schultze stated in 1978: "We can't wring this inflation out of the economy through measures which promote unemployment and economic slack. Such policies have only a limited impact on the kind of inflation from which we now suffer..." ${ }^{14}$ Note the reference to a "limited impact"-i.e., a temporary impact arising from the gap-growth channel.

\section{(vi) Inflation cannot purchase permanent gains of output above potential}

Burns repeatedly denied the existence of a tradeoff between unemployment and inflation. For example, in 1975 he stated: "Whatever may have been true in the past, there is no longer a meaningful tradeoff between unemployment and inflation.” (September 19, 1975, speech, in Burns 1978, p. 221.) He elaborated: “There was a time when there was a tradeoff, and you could see it on a chart, between inflation rates and unemployment rates. Today, the nice relationship that previously existed no longer appears. In my judgment there is no tradeoff any more.” (September 25, 1975, testimony, in Budget Committee, U.S. Senate, 1975b, p. 164.) Late in his tenure, Burns observed:

"Economists and public officials used to argue about the tradeoff between inflation and unemployment. Whether or not such a tradeoff existed in the past, I doubt that it exists at the present time.” (May 3, 1977, testimony, in Banking, Housing and Urban Affairs Committee, U.S. Senate, 1977, p. 15.)

\footnotetext{
${ }^{14}$ Quoted in Daily News (New York), March 31, 1978.
} 
In contrast to the long-run-tradeoff view, according to which higher inflation can permanently buy an excess of output above potential, Burns saw low inflation as desirable and conducive to achievement of policymakers' real goals. For example, Burns testified in 1974: "There is no conflict between the objective of maintaining the integrity of the currency and the policy declared in the [Employment] Act of 'maximum employment, production, and purchasing power." (February 26, 1974, testimony, in Joint Economic Committee, 1974, p. 757.) ${ }^{15}$ He observed in 1975: "among its several major objectives the Federal Reserve should seek over the long run to help this country return to a stable price level.” (July 24, 1975, testimony, in Banking, Currency and Housing Committee, House of Representatives, 1975, p. 219.) In 1976, Burns reaffirmed that "elimination of our disease of inflation must therefore remain a major objective of public policy." (July 27, 1976, p. 671). He went on to be more specific: "Our objective ought to be a zero rate of inflation; no other objective, I think, will serve this country well.” (July 27, 1976, testimony, in Banking, Currency and Housing Committee, House of Representatives, 1976, p. 29.)

Our recognition of Burns' rejection of a tradeoff is incorporated in the specification of equation (1): while positive gaps have a positive relation with inflation conditional on expected inflation, the coefficient on the expected-inflation term is unity, so there is no relationship between the absolute levels of inflation and the output gap in the long run.

Incidentally, if there were evidence that the Federal Reserve during the 1970s internally used Phillips-style regressions that implied a tradeoff, this would not be good evidence that the most authoritative officials believed in a tradeoff. For his part, Burns said that he took computer models "with a grain of salt" (May 1, 1975, testimony, in Banking, Housing and Urban Affairs Committee, U.S. Senate, 1975, p. 194.) He also noted: "Economists these days have made life easy for themselves by using econometric models. I must say to you that, rightly or wrongly, I do not trust the results that are wrung out of these models. The models are based on average experience over a considerable period of time. I think we have been passing through a unique period and the characteristics of this period are not built into the econometric models that economists often rely upon.” (October 2, 1975, testimony, in Budget Committee, House of Representatives, 1975, p. 180.) Burns' belief that the U.S. economy had undergone

\footnotetext{
${ }^{15}$ Other 1970s policymakers expressed similar views. For example, George Shultz, while OMB Director in 1971, said that there was a "zone of full employment with relatively stable prices," which 1960s policymakers had missed by overstimulating the economy (Omaha World-Herald, February 14, 1971).
} 
structural change that had given it a cost-plus style pricing system, would only have reinforced his skepticism about the reliability of econometric estimates.

We have found that we can characterize Burns' views with a simple equation, but we do not suggest that this was estimated or reestimated econometrically. Indeed, equation (1) is not econometrically identified using aggregate data. Burns' intuition about inflation behavior was based not on macroeconometric estimates, but on the cost-push behavior (and implied source of the $\xi_{t}$ shocks) that he thought he could observe directly at the firm and industry level.

\subsection{Why Phillips curve tradeoff ideas were not important}

Baumol and Blinder (1982, p. 301), McCallum (1989, 1995), and Taylor (1992) all argue that U.S. inflation outcomes in the 1970s reflect policymakers' belief in a permanent Phillips curve tradeoff. More recently, that hypothesis has also been advanced by Sargent (1999). We have argued that belief in a Phillips curve tradeoff was not an important factor driving U.S. policymaking in the 1970s. It is true, as Taylor (1997) notes, that an empirical Phillips curve scatter diagram was discussed in the 1969 Economic Policy Report of the President. ${ }^{16}$ But that report was issued by the outgoing administration. Statements by senior figures in the Nixon Administration in 1969 suggest they had absorbed the natural rate hypothesis. For example, the Council of Economic Advisers stated that 'there is no fixed relationship or 'tradeoff' between unemployment and inflation...” (in Joint Economic Committee, 1969, p. 334). Furthermore, U.S. monetary policy was tight during 1969 (Chairman Martin’s final year as Federal Reserve Chairman). If the 1969 policies had been continued, there would have been no Great Inflation of the Seventies. Instead, the policies of restraint ended, and were put into reverse, over 1970-72, and the cost-push view of inflation came to predominate among U.S. policymakers.

\subsection{Comparison with other interpretations}

We now compare our interpretation of U.S. official doctrine with some others available in the literature. As noted above, an early study that attributed, as we do, cost-push views

\footnotetext{
${ }^{16}$ McCallum (1989, p. 181) also cites this scatter diagram as evidence that "inflation-unemployment tradeoffs have been important in policy deliberations.”
} 
to Chairman Burns is Friedman (1972). We already have laid out some alternative interpretations of 1974-77, as well as agreement on 1971-73, with the studies of Romer and Romer (2002, 2004). We have also indicated problems with approaches (such as Sargent, 1999) that attribute Phillips-curve-tradeoff views to policymakers.

Chari, Christiano, and Eichenbaum (CCE) (1998, p. 467) claim that Chairman Burns "clearly understood" that inflation required monetary accommodation. ${ }^{17}$ But they adduce no unambiguous evidence of this allegedly clear understanding on Burns’ part. Indeed, both CCE and Christiano and Gust (2000) provide one quotation after another from Burns to the effect that excess demand no longer drives inflation and that higher growth rates of wages and other costs automatically push up inflation-i.e., affirmations of the strict cost-push position on inflation. CCE do provide one seemingly orthodox statement by Burns regarding the monetary character of inflation; it is from a 1977 speech, near the end of Burns' tenure. In portions of the speech subsequent to the orthodox statement quoted by CCE, Burns repeated his claim that the character of inflation had changed to cost-push, and acknowledged only that lower money growth would "probably” reduce inflation. ${ }^{18}$ Even late in his tenure, therefore, Burns would not grant that monetary restraint would reduce or eliminate inflation for certain, and he was emphatic that modern inflation conditions did not reflect a positive output gap. Even more crucially, via the speed-limit term in equation (1), we are able to reconcile Burns’ 1977 statement with his other statements on inflation, without attributing a monetary view of inflation to Burns.

Hetzel (1998) is an important early study that stresses Burns' cost-push views on inflation. In one passage, however, Hetzel (1998, p. 35) seems to concur with the CCE position that Burns understood that sustained inflation required monetary accommodation. But he does not reconcile this claim with Burns' many statements to the contrary; and as we have stressed, the full record of Burns' views suggests a cost-push plus speed-limit view of inflation, not a modern or standard view of inflation.

The more general message that we believe should be borne in mind is that Burns largely accepted that monetary policy could determine aggregate demand but did not, we argue, accept that the same was true of the determination of inflation. His statements about accommodation should therefore be interpreted carefully: indeed, on one occasion, Burns

\footnotetext{
${ }^{17}$ A similar view was expressed by Lombra (1980).

18 See Burns’ August 13, 1977, speech, reprinted in Burns (1978).
} 
observed, “I don’t know what ‘accommodate’ means precisely.” (March 13, 1975, testimony, in Budget Committee, U.S. Senate, 1975a, p. 835.) If one believes that monetary policy can determine $\Delta m+\Delta v$ and so the sum $\pi+\Delta y$, but that monetary policy is powerless regarding $\pi$, then "accommodation" of a higher $\Delta m+\Delta v$ rate does not imply that the policymaker is permitting higher inflation. Rather, the exogenously-determined inflation rate would (according to this view) prevail irrespective of the $\Delta m+\Delta v$ value; in these circumstances, accommodating higher nominal income growth simply corresponds to giving room for output to grow. Or as Burns once framed the issue, "This is a rather high rate of [M1] expansion by historical standards, but it is not too high when idle resources are extensive and financing needs still reflect rising prices.” (May 1, 1975, testimony, in Banking, Housing and Urban Affairs Committee, U.S. Senate, 1975, p. 172.)

\section{An estimated structural model for the United Kingdom}

We have argued that the key to understanding U.K. inflation in the 1970s was the nonmonetary approach to inflation control; and that this flawed approach has even more to answer for because of its influence on U.S. policymaking in the 1970s. In the remainder of this paper, we provide a closer look at key policymaking episodes in the United Kingdom. We do this by examining output from the Smets and Wouters (2007) model estimated on U.K. data, and illustrating how U.K. data outcomes can be understood as resulting from the flawed policy framework of the 1970s.

The model is a dynamic general equilibrium system with sticky wages and prices. ${ }^{19}$ The loglinearized version of the model is given in full in Smets and Wouters (2007), so we highlight only a few equations here. First, the monetary policy rule has the nominal interest rate $\left(R_{t}\right)$ respond to quarterly inflation $\left(\pi_{t}\right)$, the model-consistent output gap $\left(\mathrm{gap}_{t}\right)$, and the first difference of the gap:

$$
R_{t}=\rho_{R} R_{t-1}+\left(1-\rho_{R}\right)\left[r_{\pi} \pi_{t}+r_{y} g a p_{t}\right]+r_{\Delta y} \Delta g a p_{t}+e_{t}^{R}
$$

\footnotetext{
${ }^{19}$ Previous work on estimation for the United Kingdom of dynamic general equilibrium models closely related to that of Smets and Wouters (2007) includes Harrison and Oomen (2008), Li and Saijo (2008), and ourselves (2007). The last of these studies provides a defense of the use of a closed-economy model as a reasonable abstraction for the study of U.K. inflation.
} 
It is important to note that our estimation sample for this rule, as for the rest of the model, is 1962 Q1-2005 Q4, notwithstanding our emphasis on the enormous difference between 1970s and post-1979 policies. Following Ramey (1993), we interpret results from a sample that includes regime breaks as depicting average behavior of the economy. For our data and sample, the relatively low inflation periods 1962-69 and 1983-2005, and the positive mean of the real interest rate associated with those years, will imply that the estimates of rule (2) will have fairly reasonable stabilizing characteristics (e.g., $r_{\pi}$ above 1.0). It is consequently appropriate to think of the 1970s monetary policy actions as substantially consisting of deviations from this average rule, and to view these deviations as largely captured in the estimated monetary policy shock series. These deviations can be expected to be persistent, which makes it convenient for us to follow Smets and Wouters' assumption that $e_{t}^{R}$ is a stationary $\mathrm{AR}(1)$ process.

Two other equations worth highlighting are the wage and price Phillips curves:

$$
\begin{aligned}
& \pi_{t}=\pi_{1} \pi_{t-1}+\pi_{2} \mathrm{E}_{t} \pi_{\mathrm{t}+1}-\pi_{3} \mu_{t}^{p}+e_{t}^{p} \\
& w_{t}=w_{1} w_{t-1}+\left(1-w_{1}\right)\left(\mathrm{E}_{t} w_{t+1}+\mathrm{E}_{t} \pi_{t+1}\right)-w_{2} \pi_{t}+w_{3} \pi_{t-1}+w_{4}\left(m r s_{t}-w_{t}\right)+e_{t}{ }^{w} .
\end{aligned}
$$

In equation (2), $0<\pi_{1}<1$ is a function of the degree to which prices are indexed to lagged inflation; $\pi_{2}>0 ; \pi_{3}>0 ; \mu_{t}^{p}$ is the log of the inverse of real marginal cost; and $e_{t}^{p}$ is a price-equation cost-push shock. In equation (3), $w_{t}$ is the real wage, $0<w_{1}<1, w_{2}$ and $w_{3}$ are functions of the degree of indexation of wages to lagged inflation, $w_{4}>0$, and $m s_{t}$ is the typical household's marginal rate of substitution in period $t$ between consumption and contributing more labor input to production. ${ }^{20}$ The shocks to the two Phillips curves are assumed to follow univariate ARMA processes:

$$
\begin{aligned}
& \left(1-\rho_{p} L\right) e_{t}^{p}=\left(1-\mu_{p} L\right) \eta_{t}^{p} \\
& \left(1-\rho_{w} L\right) e_{t}{ }^{w}=\left(1-\mu_{w} L\right) \eta_{t}{ }^{w},
\end{aligned}
$$

where $\eta_{t}^{p}$ and $\eta_{t}{ }^{w}$ are white noise exogenous disturbances, and $L$ is the lag operator.

For our purposes, it is useful to consider the sense in which these equations contradict the cost-push view of inflation. The price Phillips curve in itself is not inconsistent with

\footnotetext{
${ }^{20}$ See Erceg, Henderson, and Levin (2000) for the justification for this type of wage Phillips curve.
} 
cost-push views, since it relates the dynamics of inflation to an average of marginal cost and to a cost-push shock specific to the price Phillips curve. But the cost-push view of inflation is largely contradicted when the wage and price Phillips curves are taken together. The wage equation makes wage inflation endogenous and, in particular, responsive in a symmetric manner to aggregate demand (via the presence of the $m r s_{t}-w_{t}$ term and the responsiveness of this term to aggregate demand). ${ }^{21}$ Because of this endogeneity, inflation is a monetary phenomenon in the model provided that $w_{4}>0$. Some elements of the cost-push view of inflation could nevertheless be salvaged if the cost-push shocks were very persistent. This would imply long systematic departures of inflation from target even if policymakers kept the output gap close to zero. ${ }^{22}$ The price Phillips curve shock is particularly important in this regard; as Smets and Wouters (2007) note, the shock term in the wage Phillips curve can be interpreted either as a wage-push shock or a specific type of preference shock (a labor supply shock). Provided the shocks in the wage equation are interpreted as labor supply shocks, they can be thought of as affecting inflation via their effect on potential output; the price equation's shocks then provide the source of the truly "cost-push" shocks in the model (i.e., the $e_{t}^{p}$ shocks in equation (3) are analogous to the $\xi_{t}$ shocks in equation (1)). ${ }^{23}$ Strong serial correlation in the price Phillips curve shock would support the idea that cost-push forces are important for medium-run inflation dynamics even without monetary accommodation. Absence of serial correlation in the cost-push shock would, by contrast, suggest that cost-push forces have only a short-run influence on inflation if not accommodated by the monetary authorities.

\footnotetext{
${ }^{21}$ Other equations of the model in turn make aggregate demand sensitive to monetary policy.

${ }^{22}$ The lagged price-inflation term in the price Phillips curve does mean that a white noise cost-push shock that is not accommodated is still propagated somewhat into expectations of future inflation. But provided that the lagged-inflation coefficient is reasonably far below unity, this propagation is quite muted: for example, with $\pi_{1} \leq 0.5$ and a $1 \%$ white-noise cost-push shock arising this period, the effect of the shock on one-year-ahead expected inflation is below $0.1 \%$. Also, note that the lagged inflation term makes inflation today sensitive to past monetary policy actions, not just to past nonmonetary forces.

${ }^{23}$ Following Smets and Wouters (2007), the estimated policy rule (2) incorporates a response to the output gap whose definition that is based on the presumption that the wage Phillips curve shocks are markup shocks that do not affect potential output. If we accept the alternative interpretation of the wage Phillips curve shock as labor supply shocks, we must think of rule (2) as incorporating mismeasurement of the output gap. Specifically, policymakers must be assumed to be erroneously excluding the labor supply shock from their definition of potential output. In that case, policymakers are responding to an output gap estimate that contains a zero-mean error arising from the misspecification of potential output behavior.
} 


\begin{tabular}{|c|c|c|c|c|c|}
\hline \multicolumn{6}{|c|}{$\begin{array}{c}\text { Table 1. Bayesian Estimates of Smets-Wouters (2007) Model on U.K. Data } \\
\text { Estimation Period 1962 Q1-2005 Q4 }\end{array}$} \\
\hline \multirow[t]{2}{*}{ Parameter } & \multirow[t]{2}{*}{ Interpretation } & \multirow{2}{*}{$\begin{array}{c}\text { Prior } \\
\text { Mean } \\
\text { (St. Dev.) }\end{array}$} & \multicolumn{3}{|c|}{ Posterior } \\
\hline & & & Mode & Mean & $5 \%, 95 \%$ \\
\hline$\varphi$ & $\begin{array}{l}\text { Capital adjustment } \\
\text { cost }\end{array}$ & $\begin{array}{c}4.00^{a} \\
(1.50)\end{array}$ & 7.60 & 7.18 & $5.55,8.73$ \\
\hline$\sigma_{c}$ & $\begin{array}{c}\text { Intertemporal } \\
\text { substitution in } \\
\text { consumption }\end{array}$ & $\begin{array}{r}1.50^{a} \\
(0.38)\end{array}$ & 1.13 & 1.43 & $1.02,1.68$ \\
\hline$h$ & Habit formation & $\begin{array}{l}0.70^{b} \\
(0.10)\end{array}$ & 0.82 & 0.53 & $0.43,0.81$ \\
\hline$\xi_{w}$ & $\begin{array}{c}\text { Probability of wage } \\
\text { adjustment }\end{array}$ & $\begin{array}{l}0.50^{b} \\
(0.10)\end{array}$ & 0.65 & 0.59 & $0.50,0.72$ \\
\hline$\sigma_{l}$ & $\begin{array}{l}\text { Labor supply } \\
\text { elasticity }\end{array}$ & $\begin{array}{r}2.00^{a} \\
(0.75)\end{array}$ & 1.90 & 1.34 & $0.65,2.33$ \\
\hline$\xi_{p}$ & $\begin{array}{c}\text { Probability of price } \\
\text { adjustment }\end{array}$ & $\begin{array}{l}0.50^{b} \\
(0.10)\end{array}$ & 0.58 & 0.63 & $0.51,0.69$ \\
\hline $\mathbf{l}_{w}$ & Wage indexation & $\begin{array}{l}0.50^{b} \\
(0.15)\end{array}$ & 0.54 & 0.50 & $0.30,0.71$ \\
\hline $\mathfrak{l}_{p}$ & Price indexation & $\begin{array}{l}0.50^{b} \\
(0.15)\end{array}$ & 0.27 & 0.28 & $0.15,0.37$ \\
\hline$\psi$ & Capital utilization & $\begin{array}{l}0.50^{b} \\
(0.15)\end{array}$ & 0.54 & 0.57 & $0.38,0.76$ \\
\hline$\Phi$ & Degree of fixed costs & $\begin{array}{l}1.25^{a} \\
(0.13)\end{array}$ & 1.79 & 1.79 & $1.64,1.93$ \\
\hline$r_{\pi}$ & $\begin{array}{l}\text { Policy response to } \\
\text { inflation }\end{array}$ & $\begin{array}{l}1.50^{a} \\
(0.25)\end{array}$ & 1.20 & 1.74 & $1.34,2.05$ \\
\hline$\rho_{R}$ & $\begin{array}{c}\text { Interest-rate } \\
\text { smoothing }\end{array}$ & $\begin{array}{l}0.75^{b} \\
(0.10)\end{array}$ & 0.85 & 0.90 & $0.86,0.93$ \\
\hline$r_{y}$ & $\begin{array}{l}\text { Policy response to } \\
\text { output gap }\end{array}$ & $\begin{array}{l}0.13^{a} \\
(0.05)\end{array}$ & 0.03 & 0.10 & $0.04,0.14$ \\
\hline$r_{\Delta y}$ & $\begin{array}{l}\text { Policy reponse to gap } \\
\text { change }\end{array}$ & $\begin{array}{r}0.13^{a} \\
(0.05)\end{array}$ & 0.10 & 0.18 & $0.10,0.22$ \\
\hline$\pi$ & Steady-state inflation & $\begin{array}{l}0.63^{c} \\
(0.10) \\
\end{array}$ & 0.59 & 0.59 & $0.46,0.72$ \\
\hline $100 \cdot((1 / \beta)-1)$ & Discounting & $\begin{array}{l}0.25^{c} \\
(0.10)\end{array}$ & 0.21 & 0.25 & $0.10,0.41$ \\
\hline$l$ & $\begin{array}{l}\text { Steady-state labor } \\
\text { (in logs) }\end{array}$ & $\begin{array}{l}0.00^{a} \\
(2.00)\end{array}$ & 5.00 & 5.49 & $3.21,8.17$ \\
\hline$\gamma$ & Balanced growth rate & $\begin{array}{l}0.40^{a} \\
(0.10) \\
\end{array}$ & 0.52 & 0.45 & $0.38,0.54$ \\
\hline$\alpha$ & $\begin{array}{l}\text { Capital share in } \\
\text { income }\end{array}$ & $\begin{array}{l}0.30^{a} \\
(0.05)\end{array}$ & 0.18 & 0.17 & $0.10,0.24$ \\
\hline
\end{tabular}




\begin{tabular}{|c|c|c|c|c|c|}
\hline \multicolumn{6}{|c|}{$\begin{array}{c}\text { Table 2. Bayesian Estimates of Smets-Wouters (2007) M } \\
\text { Estimation Period 1962 Q1-2005 Q4 } \\
\text { Estimates for Shock Processes }\end{array}$} \\
\hline \multirow[t]{2}{*}{ Parameter } & \multirow[t]{2}{*}{ Interpretation } & \multirow{2}{*}{$\begin{array}{c}\text { Prior } \\
\text { Mean } \\
\text { (St. Dev.) }\end{array}$} & \multicolumn{3}{|c|}{ Posterior } \\
\hline & & & Mode & Mean & $5 \%, 95 \%$ \\
\hline$\sigma_{a}$ & $\begin{array}{l}\text { Standard deviation of } \\
\text { technology shock }\end{array}$ & $\begin{array}{l}0.10^{c} \\
(2.00)\end{array}$ & 0.61 & 0.63 & $0.57,0.70$ \\
\hline$\sigma_{b}$ & $\begin{array}{l}\text { Standard deviation of } \\
\text { risk premium shock }\end{array}$ & $\begin{array}{l}0.10^{c} \\
(2.00)\end{array}$ & 0.51 & 0.29 & $0.20,0.50$ \\
\hline$\sigma_{g}$ & $\begin{array}{l}\text { Standard deviation of } \\
\text { spending shock }\end{array}$ & $\begin{array}{l}0.10^{c} \\
(2.00)\end{array}$ & 0.81 & 0.81 & $0.74,0.89$ \\
\hline$\sigma_{I}$ & $\begin{array}{l}\text { Standard deviation of } \\
\text { investment tech. shock }\end{array}$ & $\begin{array}{l}0.10^{c} \\
(2.00)\end{array}$ & 1.47 & 1.47 & $1.30,1.65$ \\
\hline$\sigma_{R}$ & $\begin{array}{l}\text { Standard deviation of } \\
\text { monetary policy shock }\end{array}$ & $\begin{array}{l}0.10^{c} \\
(2.00)\end{array}$ & 0.28 & 0.31 & $0.27,0.34$ \\
\hline$\sigma_{p}$ & $\begin{array}{l}\text { Standard deviation of } \\
\text { price eqn. shock }\end{array}$ & $\begin{array}{l}0.10^{c} \\
(2.00)\end{array}$ & 0.39 & 0.43 & $0.34,0.45$ \\
\hline$\sigma_{w}$ & $\begin{array}{l}\text { Standard deviation of } \\
\text { wage eqn. shock }\end{array}$ & $\begin{array}{l}0.10^{c} \\
(2.00)\end{array}$ & 0.51 & 0.54 & $0.45,0.60$ \\
\hline$\rho_{a}$ & $\begin{array}{l}\text { AR(1) for technology } \\
\text { shock }\end{array}$ & $\begin{array}{l}0.50^{b} \\
(0.20)\end{array}$ & 0.99 & 0.99 & $0.98,0.99$ \\
\hline$\rho_{b}$ & $\begin{array}{l}\text { AR(1) for risk premium } \\
\text { shock }\end{array}$ & $\begin{array}{l}0.50^{b} \\
(0.20)\end{array}$ & 0.13 & 0.60 & $0.19,0.77$ \\
\hline$\rho_{g}$ & $\begin{array}{l}\text { AR(1) for spending } \\
\text { shock }\end{array}$ & $\begin{array}{l}0.50^{b} \\
(0.20)\end{array}$ & 0.97 & 0.97 & $0.95,0.99$ \\
\hline$\rho_{I}$ & $\begin{array}{c}\mathrm{AR}(1) \text { for } \\
\text { investment tech. shock }\end{array}$ & $\begin{array}{l}0.50^{b} \\
(0.20)\end{array}$ & 0.09 & 0.14 & $0.03,0.21$ \\
\hline$\rho_{r}$ & $\begin{array}{l}\text { AR(1) for monetary } \\
\text { policy shock }\end{array}$ & $\begin{array}{l}0.50^{b} \\
(0.20)\end{array}$ & 0.36 & 0.32 & $0.23,0.45$ \\
\hline$\rho_{p}$ & $\begin{array}{l}\text { AR(1) for price } \\
\text { equation shock }\end{array}$ & $\begin{array}{l}0.50^{b} \\
(0.20)\end{array}$ & 0.97 & 0.94 & $0.89,0.99$ \\
\hline$\rho_{w}$ & $\begin{array}{l}\text { AR(1) for wage } \\
\text { equation shock }\end{array}$ & $\begin{array}{l}0.50^{b} \\
(0.20)\end{array}$ & 0.99 & 0.99 & $0.98,0.99$ \\
\hline$\mu_{p}$ & $\begin{array}{l}\text { MA(1) for price } \\
\text { equation shock }\end{array}$ & $\begin{array}{l}0.50^{b} \\
(0.20)\end{array}$ & 0.93 & 0.92 & $0.82,0.96$ \\
\hline$\mu_{w}$ & $\begin{array}{l}\text { MA(1) for wage } \\
\text { equation shock }\end{array}$ & $\begin{array}{l}0.50^{b} \\
(0.20)\end{array}$ & 0.88 & 0.87 & $0.81,0.94$ \\
\hline$\rho_{g a}$ & $\begin{array}{l}\text { Correlation, spending } \\
\text { and technology shocks }\end{array}$ & $\begin{array}{l}0.50^{a} \\
(0.25)\end{array}$ & 0.50 & 0.49 & $0.34,0.65$ \\
\hline
\end{tabular}


For our estimation, we use observations on the U.K. nominal Treasury bill rate, quarterly retail price inflation, ${ }^{24}$ quarterly wage inflation, and per-capita values of log real GDP, log real consumption, log real investment, and log aggregate hours. GDP, consumption, investment, and real wages are assumed to share a loglinear trend. ${ }^{25}$

Estimates of the model using Smets and Wouters' Bayesian procedure are given in Tables 1 and 2. We focus the discussion on the estimates of the Phillips curves discussed above. First, we note that wages are estimated to depend on the discrepancy between the marginal rate of substitution and the real wage: the implied value of $w_{4}$ in equation (4) is 0.02 irrespective of whether the mode or mean value of the posterior distribution is used. Therefore, this condition for inflation to depend symmetrically on monetary policy actions is satisfied, rejecting one aspect of cost-push analysis. Second, we note from Table 2 that the price cost-push shock term has only minor estimated persistence: although its $\mathrm{AR}(1)$ coefficient is over 0.90 (mode 0.97 , mean 0.94 ), so too is the accompanying MA(1) coefficient (mode 0.93, mean 0.92), implying that a common factor virtually cancels from the dynamics of equation (5) and delivers a near-white noise cost-push process. ${ }^{26}$ Third, the value of $\pi_{1}$ in equation (3) is moderate: using the mode values of these estimates, the implied value of $\pi_{1}$ is 0.21 ; using the mean values, it is 0.22. The dynamics of the price Phillips curve therefore do little to propagate a cost-push shock. Taken together, these results suggest that U.K. policymakers were wrong to attribute inflation movements to long-lasting special factors and to dismiss the scope for monetary policy to influence inflation.

Table 3 gives variance decompositions for the estimated model. For horizons of four quarters ahead or more, monetary policy shocks account for about $11 \%$ or more of variation in both inflation and output growth; indeed, for inflation they account for nearly $20 \%$ of the forecast error variance at a two- to three-year horizon. Several VAR studies

\footnotetext{
${ }^{24}$ In contrast to the series plotted in Figure 1, the retail price inflation series used in estimation excludes mortgage costs. It also removes effects on the index of tax increases in 1979 and 1990. The adjustments are described in DiCecio and Nelson (2007).

${ }^{25}$ Data sources for most of the series are given in DiCecio and Nelson (2007). The remaining data required for the VAR used here are: population (for which we use Darby and Lothian (1983) data to 1971, spliced into the U.K. Office of National Statistics (ONS) series mgsl.q after 1971) and a nominal wage index (total compensation, ONS series dtwm.q, divided by employment, obtained by British Labour Statistics data up to 1978 , spliced into ONS series bcaj.q).

${ }^{26}$ There is substantial, but less complete, cancellation of the AR and MA terms underlying the wage shock process too.
} 
for the United States find a lower fraction of output forecast error variance accounted for by monetary shocks at business cycle horizons than we obtain for the United Kingdom, Table 3. Forecast Error Variance Decompositions at Horizon $k$

\begin{tabular}{|c|c|c|c|c|c|c|c|c|c|c|c|c|c|c|}
\hline & $\varepsilon_{a}$ & $\varepsilon_{b}$ & $\varepsilon_{q}$ & $\varepsilon_{I}$ & $\varepsilon_{R}$ & $\varepsilon_{p}$ & $\varepsilon_{w}$ & $\varepsilon_{a}$ & $\varepsilon_{b}$ & $\varepsilon_{q}$ & $\varepsilon_{I}$ & $\varepsilon_{R}$ & $\varepsilon_{p}$ & $\varepsilon_{w}$ \\
\hline & \multicolumn{7}{|c|}{$k=1$} & \multicolumn{7}{|c|}{$k=12$} \\
\hline$\Delta y$ & 6.7 & 33.1 & 30.4 & 20.9 & 7.6 & 1.1 & 0.3 & 7.3 & 30.1 & 26.2 & 18.5 & 11.6 & 1.6 & 4.8 \\
\hline$\Delta c$ & 1.2 & 87.8 & 0.1 & 0.1 & 10.4 & 0.3 & 0.2 & 3.9 & 72.4 & 0.5 & 0.2 & 14.4 & 0.9 & 7.8 \\
\hline$\Delta i$ & 0.5 & 6.4 & 0.1 & 86.6 & 5.6 & 0.7 & 0.1 & 1.9 & 6.1 & 0.4 & 78.9 & 8.7 & 1.6 & 2.4 \\
\hline$l$ & 20.6 & 27.7 & 27.0 & 18.3 & 6.0 & 0.2 & 0.1 & 7.8 & 11.7 & 17.5 & 6.2 & 22.0 & 5.5 & 29.3 \\
\hline$\pi$ & 2.2 & 1.1 & 0.8 & 0.1 & 8.2 & 62.8 & 24.7 & 2.7 & 1.6 & 2.1 & 0.2 & 19.2 & 17.8 & 56.4 \\
\hline$\Delta w$ & 1.2 & 4.1 & 0.1 & 0.4 & 2.6 & 25.5 & 66.1 & 3.2 & 4.1 & 0.3 & 0.7 & 6.2 & 23.4 & 62.2 \\
\hline \multirow[t]{2}{*}{$R$} & 2.2 & 17.5 & 1.0 & 0.8 & 62.8 & 8.7 & 6.9 & 5.0 & 7.8 & 4.9 & 1.1 & 19.4 & 4.3 & 57.5 \\
\hline & \multicolumn{7}{|c|}{$k=4$} & \multicolumn{7}{|c|}{$k=30$} \\
\hline$\Delta y$ & 7.4 & 31.3 & 27.9 & 19.4 & 10.9 & 1.6 & 1.6 & 7.3 & 29.8 & 26.0 & 18.3 & 12.0 & 1.6 & 5.0 \\
\hline$\Delta c$ & 3.2 & 78.3 & 0.3 & 0.2 & 14.2 & 0.9 & 2.8 & 3.9 & 71.7 & 0.5 & 0.2 & 14.8 & 0.9 & 8.0 \\
\hline$\Delta i$ & 1.6 & 6.2 & 0.3 & 81.8 & 8.0 & 1.6 & 0.5 & 1.9 & 6.1 & 0.5 & 78.2 & 9.1 & 1.7 & 2.5 \\
\hline$l$ & 14.8 & 22.8 & 24.5 & 12.5 & 21.2 & 2.1 & 2.1 & 4.6 & 5.6 & 10.1 & 3.2 & 10.7 & 4.2 & 61.6 \\
\hline$\pi$ & 3.2 & 1.9 & 1.7 & 0.2 & 17.6 & 27.7 & 47.8 & 2.8 & 1.4 & 2.2 & 0.4 & 16.6 & 15.4 & 61.3 \\
\hline$\Delta w$ & 2.5 & 3.9 & 0.2 & 0.7 & 5.7 & 24.5 & 62.5 & 3.1 & 4.0 & 0.3 & 0.7 & 6.7 & 23.2 & 61.8 \\
\hline \multirow[t]{2}{*}{$R$} & 4.9 & 13.4 & 3.2 & 1.5 & 40.9 & 7.8 & 28.3 & 4.8 & 5.1 & 4.9 & 1.2 & 13.1 & 3.0 & 67.9 \\
\hline & \multicolumn{7}{|c|}{$k=8$} & \multicolumn{7}{|c|}{$k=100$} \\
\hline$\Delta y$ & 7.4 & 30.7 & 26.7 & 18.8 & 10.8 & 1.6 & 4.0 & 7.4 & 29.7 & 25.9 & 18.3 & 12.0 & 1.7 & 5.2 \\
\hline$\Delta c$ & 3.9 & 74.3 & 0.4 & 0.2 & 13.7 & 0.9 & 6.5 & 4.0 & 71.3 & 0.5 & 0.2 & 14.7 & 0.9 & 8.3 \\
\hline$\Delta i$ & 1.9 & 6.2 & 0.4 & 79.9 & 8.0 & 1.6 & 1.9 & 2.0 & 6.0 & 0.5 & 78.0 & 9.1 & 1.7 & 2.7 \\
\hline$l$ & 10.4 & 15.9 & 21.1 & 8.5 & 26.4 & 4.5 & 13.2 & 6.2 & 3.5 & 7.1 & 2.1 & 6.7 & 2.8 & 71.6 \\
\hline$\pi$ & 2.8 & 1.7 & 1.9 & 0.2 & 19.7 & 19.8 & 53.8 & 4.2 & 1.1 & 2.0 & 0.3 & 12.8 & 12.2 & 67.4 \\
\hline$\Delta w$ & 3.1 & 4.0 & 0.3 & 0.7 & 5.7 & 23.9 & 62.3 & 3.2 & 4.0 & 0.3 & 0.7 & 6.7 & 23.3 & 61.7 \\
\hline$R$ & 5.4 & 9.9 & 4.6 & 1.3 & 24.2 & 5.4 & 49.1 & 7.5 & 3.0 & 3.7 & 0.9 & 7.6 & 2.4 & 74.9 \\
\hline
\end{tabular}

Note: Numbers reported are estimated percent contribution of the innovation to the variance of the row variable. The innovations (column headers) are to technology $\left(\varepsilon_{a}\right)$, the risk premium $\left(\varepsilon_{b}\right)$, spending $\left(\varepsilon_{g}\right)$, investment technology $\left(\varepsilon_{I}\right)$, the monetary policy rule $\left(\varepsilon_{R}\right)$, the price Phillips curve $\left(\varepsilon_{p}\right)$, and the wage Phillips curve $\left(\varepsilon_{w}\right)$. The endogenous variables (row headers) are output growth $(\Delta y)$, consumption growth $(\Delta c)$, investment growth $(\Delta i)$, $\log$ hours $(l)$, price inflation $(\pi)$, wage inflation $(\Delta w)$, and the short-term interest rate $(R)$. 
while Cochrane (1998) argues that monetary policy shocks contribute trivially to the forecast error variance of U.S. inflation. The comparatively larger fractions that we find in our estimated structural model may be due to our use of U.K. data instead of U.S. data. But more likely, they are largely due to our deliberately imposing a constant-parameter policy rule over the whole sample. As noted above, this choice magnifies the variance of the deviations from the estimated full-sample rule. Effects of monetary policy are therefore likely to be manifested to a greater degree as contributions of monetary policy shocks to the variance of the model variables-rather than indirectly as the effects of the monetary policy rule on the transmission of the non-policy shocks.

The wage Phillips curve and price Phillips curve shocks account for a large share of the variation in the nominal variables, while the wage Phillips curve shock accounts for a large fraction of the variation of hours, reinforcing our inclination to interpret it as a labor supply shock. Interest-rate decisions are driven by the wage Phillips curve innovation, because that innovation is part of a persistent shock process; by contrast, the price Phillips curve innovation accounts for a far smaller amount of interest-rate variation.

\subsection{Great Inflation episodes}

In Figure 2a, we plot the short-term nominal interest rate and four-quarter inflation in the United Kingdom for 1969 Q4-1979 Q2. In Figure 2b we plot the arithmetic first differences of these two series, which helps somewhat to isolate the responsiveness (in sign and magnitude) of monetary policy to movements in inflation. ${ }^{27}$ In Figure 2c we plot the behavior of the model's estimated U.K. monetary policy shocks over the 1970 s. $^{28}$ As foreshadowed above, several of the observations on the monetary policy shock are notably negative in the 1970s, reflecting expansionary departures of monetary policy from the more orthodox rule estimated over 1962-2005. Four episodes stand out:

- There is a steeply negative value of the monetary policy shock in 1971 Q2. In April 1971, the Government cut interest rates by $1 \%$ despite the fact that inflation was rising. The Government was relying on its direct influence on specific prices (for example, on

\footnotetext{
${ }^{27}$ That is, Figure 2b plots $400 *\left(R_{t}-R_{t-1}\right)$, where $R_{t}$ is the nominal interest rate in quarterly fractional units; and $\pi_{t}^{A}-\pi_{t-1}^{A}$, where $\pi_{t}^{A}=100 *\left(\left[P_{t}-P_{t-4}\right] / P_{t-4}\right), P_{t}$ being the unlogged price level.

28 The shocks are constructed from the data and the median parameter estimates via the Kalman smoother. The Kalman smoother seems a more natural method for generating shocks than the Kalman filter in cases such as ours where the assumption underlying model estimation is that the structural parameters and the policy rule responses are time-invariant (see Hamilton, 1994, p. 394).
} 
Figure 2a. Nominal interest and four-quarter inflation rates, U.K., 1969 Q4-1979 Q2

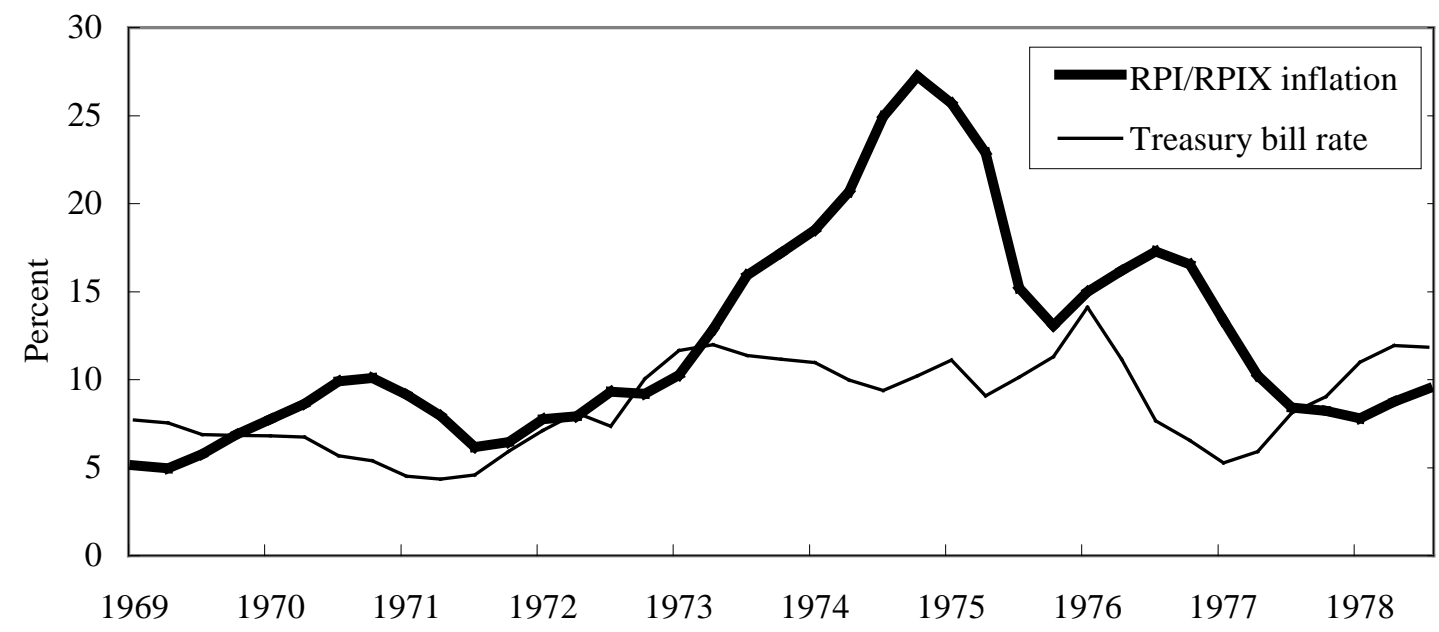

Figure 2b. Nominal interest and inflation rates, first differences, U.K., 1969 Q4-1979 Q2

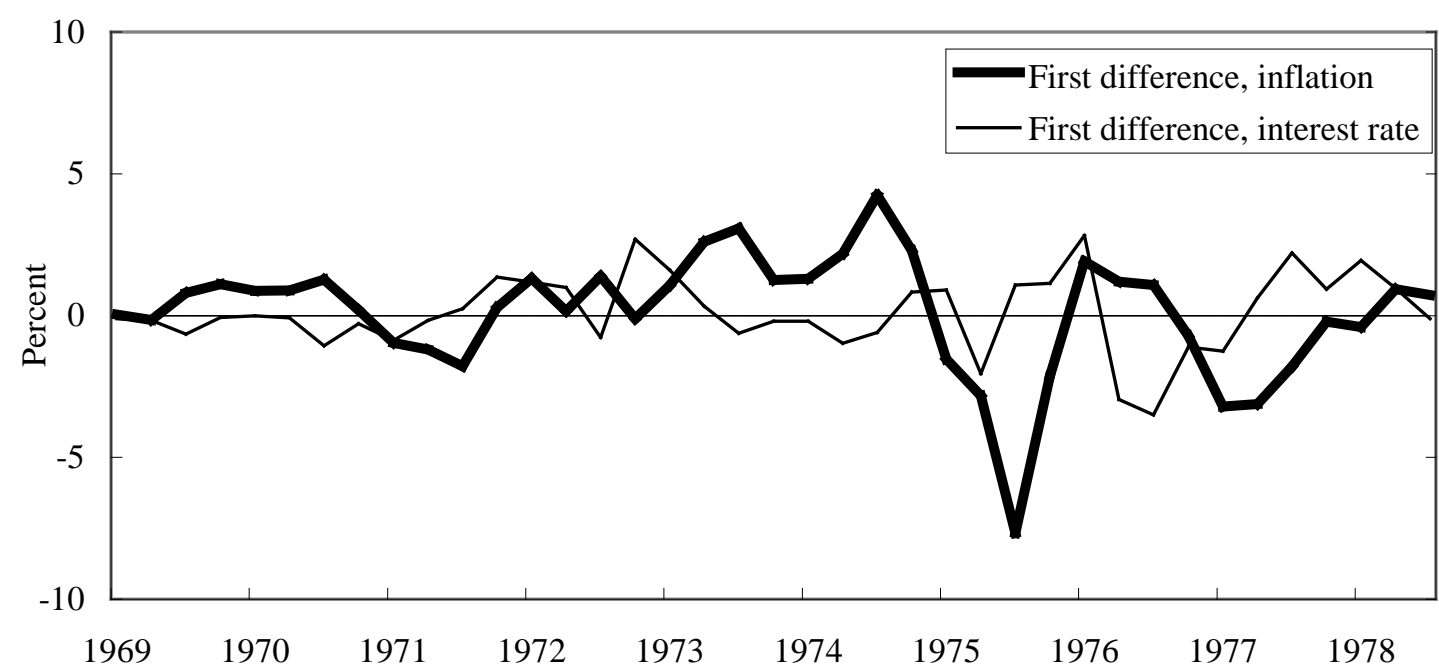

Figure 2c. Estimated monetary policy shocks, U.K., 1969 Q4-1979 Q2

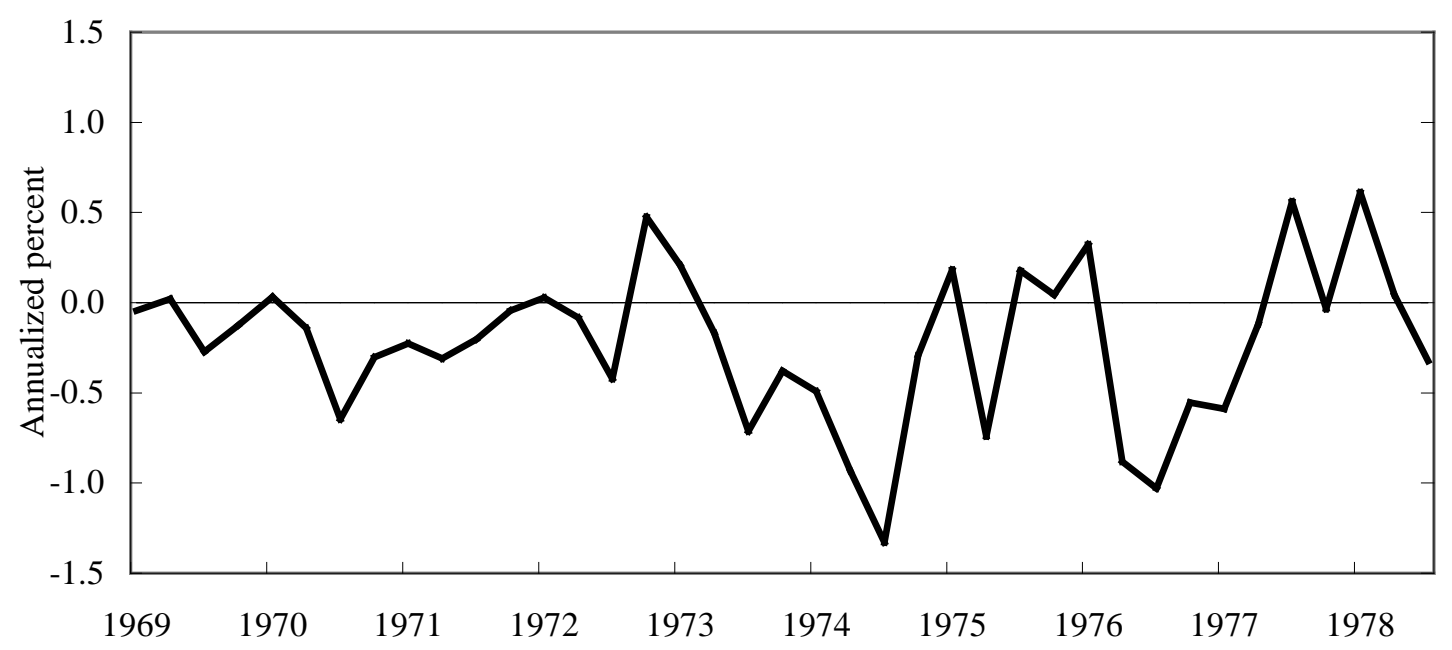


utilities prices) to control inflation. It even saw expansionary monetary policy as reducing inflationary pressure, on the grounds that output growth diluted unit labor cost growth (the denominator in the unit labor cost expression-nominal wages-being perceived as out of reach of monetary policy actions).

- There are some substantial, negative monetary policy shocks from 1974 Q2 to 1976 Q1. Even one former insider on U.K. policymaking seemed to be at a loss to explain monetary policy over this period: Cairncross (1992, pp. 215-216) observes, "For some reason monetary policy had remained remarkably relaxed in Labour's first two years [i.e., to March 1976], with bank rate (or MLR [Minimum Lending Rate]) falling from 13\% to 93/4 in April 1975, rising to 12\% in October 1975 and then falling again to 9\% in March 1976." What is more, even the maximum level of the nominal interest rate over this period was well below the inflation rate, and several of the rate cuts were against the background of rising inflation. Faulty measures of the output gap do not seem to account for the extent of the ease of U.K. monetary policy over this period. ${ }^{29}$ The reason for the relaxed stance of monetary policy seems to be the U.K. authorities' heavy reliance on wages policies (the series of "Social Contract" agreements between the Government and unions) and their parallel belief that monetary policy tightening would not bring inflation down.

- In 1977, there is a series of negative monetary policy shocks as nominal interest rates were brought down into single digits despite double-digit inflation. This period was again one characterized by reliance on the Social Contract as the inflation-fighting tool.

- Another notable negative monetary policy shock occurs in 1979 Q2. In April 1979, the U.K. Government cut interest rates by $1 \%$ despite the fact that inflation was rising. This decision followed the Government's signing of a new agreement with the unions, again intended to fight inflation by direct restraint of wages.

These results from the estimated model illustrate our contention that while inflation in the United Kingdom in the 1970s was not in fact a cost-push process, the policy choices that led to the Great Inflation are traceable to the authorities’ adherence to cost-push views.

\footnotetext{
${ }^{29}$ See Nelson and Nikolov (2004).
} 


\subsection{Other explanations for the U.K. policy episodes}

Let us consider some more benign interpretations of the monetary policy easings that took place in the United Kingdom during the 1970s. One such interpretation is based on the fact that the U.K. stockmarket underwent an extraordinary decline during the 1970s. The Financial Times stockmarket index in 1974 was as low in nominal terms as it had been in the late 1950s (see, e.g., Bordo and Wheelock, 2004). Could this stockmarket behavior justify the pattern of U.K. monetary policy decisions in the mid-1970s, explaining why nominal interest rates were so low compared with inflation rates? To us this proposed justification is weak. It may explain partially why policymakers behaved the way they did, but it does not establish that a tighter and more orthodox monetary policy would not have been superior. We first note that if a period is associated with stockmarket weakness, that is not generally a sufficient reason in the monetary policy rules literature for rejecting comparison of actual policy decisions with simple rules based on macroeconomic aggregates. For example, the U.S. stockmarket was weak in the 1970s, yet it is standard to compare actual policy against rules that respond only to inflation and an index of real aggregate activity such as the output gap, detrended output, or output gap growth (see, e.g., Orphanides, 2003). Policymakers concerned with macroeconomic stabilization should not care about stockmarket weakness per se. And monetary policy rules that respond to stock prices are not likely to contribute to macroeconomic stabilization better than rules that concentrate purely on responding to inflation and aggregate economic activity. Because the relationship between stock prices and macroeconomic aggregates tends to be very loose in practice, interest-rate responses to stock prices are likely to detract from macroeconomic stabilization.

It also deserves emphasis that the weakness of the stockmarket was largely a symptom of the faulty U.K. policy framework in place in the 1970s-i.e., of highly inflationary policy accompanied by nonmonetary interventions. These nonmonetary interventions were distortions that worsened for private corporations the costs of high inflation rates. Direct controls on prices, profits, and dividends, alongside an unindexed taxation system, magnified the collapse of the stockmarket (as well as other U.K. markets for corporate capital, such as the debenture market, which contracted dramatically in the mid-1970s). Among their other effects, the nonmonetary measures against inflation meant that prices were not allowed to have their optimal relation to costs, intensifying the squeeze on corporate liquidity in the mid-1970s. The U.K. monetary policy easings in 1974-76 may have been partly undertaken to lessen this squeeze. For example, policymakers may have 
been more inclined to boost aggregate demand on the grounds that this would hold down nominal unit costs and also restrain unit cost growth relative to inflation. But that rationale for monetary policy easing reflects the flawed U.K. doctrinal framework, with its neglect of the links between aggregate demand and inflation. Efforts to hold down or reduce interest rates may well have helped ease the corporate liquidity situation, but they also contributed to the expansionary monetary policies responsible for high inflation.

Another rationalization for the policy easings of the 1970s might be found in the fact that the price index used to compute the "headline" inflation series in the United Kingdom, the Retail Price Index, gives a heavy weight to mortgage costs. This factor is not relevant to the consideration of the 1971 monetary policy easing, because the inclusion of mortgages in the RPI began only in the mid-1970s (Lawson, 1992, p. 849). But, for the other easing periods examined above, it could conceivably be argued that an easing was justified by the connection between mortgages and price inflation. Might policymakers have thought that cutting policy rates would reduce mortgage rates, thereby helping to reduce RPI inflation pressure, and perhaps producing a favorable wage-price spiral via links between the RPI and wages? Again, such rationales might help explain U.K. policy decisions in a positive-economics sense, but do not seem to us provide a good economic justification for those decisions. Any thinking by policymakers along "mortgage rate/price/wage spiral” lines is valid only in the faulty nonmonetary framework of inflation analysis. Judged from a more orthodox position on inflation determination, the "spiral" view is invalid except as a description of the very short run. Interest-rate cuts aimed at provoking mortgage rate cuts might deliver short-term inflation benefits, but do so at the cost of long-term inflation control. Over the long run, RPI behavior is similar to that of indices of U.K. prices that exclude mortgage costs, such as the RPIX series and the modern CPI. Fundamentally, this is because long-term inflation behavior is driven by aggregate demand, swamping shorter-term influences on inflation. Interest-rate cuts ultimately raise RPI inflation via the stimulus to demand, so the cuts do not have a sound foundation as an inflation-control measure.

We therefore find no legitimate basis for the policymaking framework followed in the United Kingdom during the 1970s in either stockmarket or mortgage rate behavior. 


\section{Conclusion}

Economic policy in the United Kingdom during the 1970s was guided by a doctrinal framework that suggested that inflation arose from nonmonetary factors and could — and only could - be brought down by nonmonetary measures. This contrasts with the modern policymaking framework in many countries, which is guided by the notion that monetary restraint — and only monetary restraint - is the way to control inflation. We have argued that policymakers' adherence to the older doctrinal framework is useful for understanding why they made the mistakes that led to U.K. inflation outcomes in the 1970s. Seemingly nonstandard interest-rate decisions during the 1970s can be understood as a consequence of policymakers using this framework, even though the decisions are unjustifiable from the point of view of more enlightened economic theory. Moreover, the U.S. Great Inflation of the Seventies can be understood as arising from U.S. policymakers' embrace of the U.K. nonmonetary framework. After pursuing an orthodox policy against inflation during 1969 — which would have avoided the 1970s Great Inflation if it had been continued-U.S. policy circles in the early 1970s inherited the faulty doctrine already in place in the United Kingdom. The similarities of the U.S. and U.K. Great Inflation experiences can therefore be seen as arising not from common shocks, but from common errors in policymaking doctrine. 


\section{Appendix A. U.S. policy against inflation during the 1960s}

Wage-price guideposts-i.e., federal government announcements giving recommendations for the maximum increases to take place in private sector wages and prices, sometimes laid out on an industry-by-industry basis - were used as an antiinflation measure by the Kennedy and Johnson Administrations during the 1960s. In this Appendix, we show that the thinking underlying these measures was not the same as that underlying the 1971-74 U.S. wage and price controls and other 1970s nonmonetary measures against inflation. We thereby reaffirm our position that 1970s U.S. policy on inflation arose from the adoption by 1970s U.S. policymakers of U.K. cost-push views, rather than from a continuation of the doctrines adhered to by 1960s U.S. policymakers. ${ }^{30}$

We summarize the issues involved ahead of our detailed discussion. The major, and most authoritative, proponents of guidelines explicitly rejected the nonmonetary (a.k.a. pure cost-push) view of inflation. As we detail below, the 1961-68 policymaking view was not as orthodox or modern as that prevailing in 1969-70, but it did share with the 1969-70 and modern positions the view that inflation was sensitive to both positive and negative output gaps. It follows that policymakers accepted that aggregate demand measures by themselves could produce price stability: i.e., they conceded that monetary policy measures that resolutely restricted the level of aggregate demand would, if applied, be sufficient to remove all inflationary pressure. Policymakers opposed such an application, however, and instead favored a mix of aggregate demand and guideline policies. Guidelines had value, according to this view, as a complement to aggregate demand measures, and specifically could improve the inflation rate achievable under full employment; but if price stability was desired and guidelines were unavailable, it was accepted that aggregate demand measures were capable of securing price stability.

The 1970s U.S. doctrine departed from both the 1960s U.S. official position and modern views by embracing the "British" position that inflation was insensitive to negative output gaps. Monetary policy measures by themselves could not remove all inflationary pressure according to the 1970s view: i.e., it was believed that even with demand restricted to a low level, prolonged inflation could occur. Pure cost-push inflation

\footnotetext{
${ }^{30}$ As a related matter, we aim to show that our reference to the "Great Inflation of the Seventies" as a distinct entity is not a denial that the United States had an inflation problem during the 1960s; therefore, it is not subject to the criticism of Levin and Taylor (2008).
} 
consequently could occur according to the 1970s doctrinal framework, so inflation was viewed as a nonmonetary phenomenon.

\section{A1. Samuelson and Solow}

Prior to considering policymakers' views, we first consider the rationale for the U.S. guideposts of the 1960s offered by Paul Samuelson and Robert Solow. Though neither was officially affiliated with the Johnson Administration, they were affiliated with the 1960-61 Kennedy transition and 1961-63 Kennedy Administration, and were the most prominent scholarly defenders of the guidepost policies.

As is well known, Samuelson and Solow (1960) are associated with a simple Phillips curve of the type:

$\pi_{t}=a_{0}+a_{1} \mathrm{E}\left(u_{t}-u_{t}^{*}\right)$

or the same specification with an expectational term:

$\pi_{t}=a_{0}+a_{1} \mathrm{E}\left(u_{t}-u_{t}^{*}\right)+a_{2} \mathrm{E}_{t} \pi_{t+1}$

with $a_{1}<0, u_{t}^{*}$ being the natural unemployment rate. We include a rational expectation of inflation in specifying the dynamic Phillips curve above. It is true that an element of 1960s and 1970s controversies on inflation determination was how expectations were formed-e.g., whether the expected-inflation variable should consist of lagged inflation with unit coefficient, lagged inflation with nonunit coefficient, or a rational expectation of current or future inflation. But this controversy is not germane to the issue of a tradeoff between inflation and unemployment, which can emerge even with a rational expectation of inflation provided that the expectation has a coefficient $a_{2}$ differing from unity (specifically, $0<a_{2}<1$ ).

The dynamic equation has a long-run form:

$\mathrm{E}[\pi]=b_{0}+b_{1} \mathrm{E}\left[\left(u-u^{*}\right)\right]$

with $b_{0}=a_{0} /\left(1-a_{2}\right), b_{1}=a_{1} /\left(1-a_{2}\right)$. 
Some observers have interpreted the position that policymakers tried to exploit a perceived inflation/unemployment tradeoff as implying policymaker belief in this longrun condition coupled with a target for unemployment below the full-employment or natural rate; that is, an objective for unemployment of $E\left[\left(u-u^{*}\right)\right]<0$. But this does not appear to be what 1960s advocates of a long-run Phillips curve relation had in mind in speaking of a tradeoff; rather, the employment target was characterized as a fullemployment concept, with the associated unemployment rate being a distinct value pinned down by real factors. Furthermore, at the policy level, Federal Reserve Chairman Martin articulated in 1967 the desirability of avoiding "a situation of overfull employment and overutilization of resources” (February 9, 1967, testimony, in Joint Economic Committee, 1967, p. 416).

If the policymaker goal for real variables amounted to a zero output (and unemployment) gap, how does the Samuelson-Solow relation imply a long-run policymaking dilemma? Let us add a shock term to the dynamic Phillips curve,

$\pi_{t}=a_{0}+a_{1} \mathrm{E}\left(u_{t}-u_{t}^{*}\right)+a_{2} \mathrm{E}_{t} \pi_{t+1}+\xi_{t}$

Samuelson and Solow (1960) stressed the importance of variations in $\xi_{t}$ and, as did later authors, they labeled it a "cost-push" factor. Provided it has a zero mean, however, this shock term does not generate a long-run tradeoff between inflation and real variables. The shock term produces a tradeoff in variances, not in means, and continues to do so if a long-run vertical Phillips curve replaces the one studied by Samuelson and Solow (1960). (See Taylor, 1979, 1986.)

If the cost-push shock term has a nonzero mean, then we can decompose the long-run intercept of the Phillips curve as $b_{0}=\pi^{*}+\mathrm{E}[\xi]$, where $\pi^{*}$ is the inflation rate corresponding to price stability and $\mathrm{E}[\xi]$ is the mean of the $\xi_{t}$ series. Then

$\mathrm{E}[\pi]=\pi^{*}+\mathrm{E}[\xi]+b_{1} \mathrm{E}\left[\left(u-u^{*}\right)\right]$

It is the long-run nonvertical, nonzero-mean shock term that delivers the tradeoff or policy dilemma that Samuelson and Solow (1960) emphasized. Samuelson and Solow argued that inflationary momentum arising from cost-push sources meant that $E[\xi]$ could not be counted on to be zero. Samuelson (1969) stated: “In 1960, when I prepared for President[-Elect] Kennedy a report on the State of the American Economy, I had to 
express pessimism concerning the ability of any mixed economy to achieve price stability along with full employment and free markets.” (Emphasis in original.)

Similarly, Samuelson (1961) commented, "there is reason to fear that the cost-push spiral of creeping inflation may come back into being in 1962 while unemployment is still at the socially undesirable level of more than 5 percent." In 1970, he asked, "What can be done about cost-push inflation, this scourge that makes it impossible to have both full employment and price stability?” (Samuelson, 1970.)

The guidepost policy came into force in the United States in 1962. Subsequently, Samuelson (1968, p. 60) argued that while a (permanently nonvertical) Phillips curve relation continued to be a structural feature underlying U.S. data, guideposts could produce deviations from the historical curve by decreasing the mean of cost-push shocks:

"All these studies pick up what we all thought was there, namely, a strong costpush element in the 1955-57 data... There is a plus residual continuing for many quarters in that earlier period and there is a negative residual in the 1960s.”

Reflecting this view, Solow (1968, p. 13) added an intercept-dummy variable when including post-1962 observations in his estimated Phillips curve equation, so as to capture the favorable effects on mean inflation claimed for the guidepost policies.

Samuelson and Solow repeatedly reaffirmed in the 1960s that they did not envision inflation as a pure cost-push phenomenon a la the U.K. (and also later, Burns') conception. It was a time-varying intercept—equivalently, a Phillips curve shock term of nonzero mean - which was the source of a tradeoff or policy dilemma, if aggregate demand policies alone were used to control inflation. The presence of this term was not seen as precluding a symmetric Phillips curve relation, whereby inflation depended continuously on unemployment or output gaps.

This position - that the tendency for the intercept of the Phillips curve to take undesirably high values, makes it appropriate to take guidepost measures against wages and pricesmust be distinguished fundamentally from the pure cost-push position-i.e., that no Phillips relation holds below full employment, leaving incomes policy the only feasible instrument against inflation. Solow made it explicit that his support for guidelines did not rest on a pure cost-push view of inflation: 
"I want to make this very clear. I am not resting my case on a theory of cost-push inflation... [but instead] only on the degree of tightness in the economy at which the price level begins to rise unacceptably rapidly.” (Solow, 1966, p. 64; emphasis in original.)

Thus Solow wanted to reduce the mean value of cost-push forces so that the permanently nonvertical Phillips curve, though implying an inverse relation between inflation and gaps, did not imply a tradeoff between these series. Solow's was not a modern view of inflation, due to his acceptance of a permanent tradeoff and his fear of a nonzero mean cost-push shock; but equally, it was not a 1970s-type view of inflation, because Solow accepted that inflation did respond continuously to monetary policy via an output gap channel.

\section{A2. Policy-level doctrine}

Federal Reserve. It is unclear whether Federal Reserve Chairman Martin believed in a long-run tradeoff between inflation and unemployment. But he recognized the need to avoid overfull employment, as noted above; so, even if he had a nonvertical Phillips curve in mind, his aims did not include exploiting it to purchase output levels in excess of potential output.

As far as cost-push views are concerned, Chairman Martin in the mid-1960s was not a believer in pure cost-push theories of inflation, but he did see cost-push elements as a component of inflation (see his February 9, 1967, testimony, in Joint Economic Committee, 1967, p. 421). Aggregate demand measures were not "necessarily the right tool” in the face of cost-push inflation, but were essential in the absence of other tools being applied (ibid, p. 422); and restraint of aggregate demand could limit the extent to which inflation responded to cost-push forces (ibid, p. 425).

Administration personnel. In 1966, Treasury Secretary Fowler conceded that pursuit of price stability via aggregate demand measures alone was feasible:

“The administration included price stability as a goal to be sought along with... full employment and a healthy rate of growth. It believes that there is a fundamental compatibility of these three objectives and that in seeking one of them it is unwise to sacrifice the others. If one objective, such as price stability or 
full employment, is sought with the utmost vigor without concern for the others, that is not wise national policy." (February 3, 1966, testimony, in Joint Economic Committee, 1966, p. 180.)

As the above quotation indicates, and in contrast to the case in the 1970s, the use of incomes policy as an anti-inflation instrument was seen by 1960s policymakers as desirable so as to avoid the need for trading off goals; it did not constitute a denial that, in principle, aggregate demand measures alone could deliver price stability. In keeping with this perception, CEA Chairman Gardner Ackley saw guideposts as moving pricing decisions in a direction which removed the need to trade off unemployment and inflation:

"We begin with the fundamental premise that this Nation must be able to enjoy the benefits of both high employment and price stability. We conclude that the wageprice guideposts offer the best opportunities for encouraging behavior which will reconcile these two key objectives.” (February 19, 1965, testimony in Joint Economic Committee, 1965, p. 6.)

This statement, like those of Martin, Samuelson, and Solow, reflects a view of inflation crucially different from pure cost-push view common to United Kingdom in the 1960s and 1970s and to the United States in the 1970s. Despite his appeal to the presence of cost-push elements in the pricing process, Ackley's statements imply that cost-push shock elements' effect on inflation can be counteracted by a maintained negative output gap. Cost-push elements existed according to 1960s U.S. policy doctrine, and were a source of a tradeoff (or, as Ackley put it, “of an inflationary bias of the economy at full employment”); ${ }^{31}$ but 1960s U.S. doctrine did not deny that, in principle, a desired inflation rate could be secured solely by the fixing of aggregate demand at a certain level.

\section{A3. U.S. policy in 1969-70}

As discussed in the main text, 1969 saw two important changes in official U.S. doctrine. First, there was an explicit embrace of no-long-run tradeoff view, as documented in the text from CEA statements. ${ }^{32}$ Secondly, the Administration (which initially included Arthur Burns as a White House advisor, prior to his move to the Federal Reserve in 1970) took a truly monetary view of inflation by arguing that incomes policy was not necessary

\footnotetext{
${ }^{31}$ Ackley (1966, p. 78).

${ }^{32}$ Romer (2007, pp. 10-11) similarly notes that late 1960s U.S. policymakers rejected any long-run tradeoff.
} 
to eliminate inflation or to remove a long-run tradeoff. The previous Administration's position that there was an inherent tendency for cost-push forces to have a zero average effect on inflation, even in the absence of monetary accommodation, was not continued.

This new doctrine had a very short-lived initial influence on policy due to changes in views by Chairman Burns during 1970 and by the Nixon Administration thereafter; but it was distinct, as we have stressed, from both pre-1969 and 1971-79 policymaker views. 


\section{Appendix B. Bibliographical information}

\section{B1. Material from Federal Reserve publications}

November 11, 1971: "Summary of Remarks by Arthur F. Burns, Board of Governors of the Federal Reserve System, at the New York Stock Exchange.” (http://fraser.stlouisfed.org/historicaldocs/statements/download/28999/Burns_19711111.pdf).

August 6, 1974: Burns’ statement before the Joint Economic Committee (http://fraser.stlouisfed.org/historicaldocs/statements/download/28175/Burns 19740806.pdf).

August 21, 1974: Burns’ statement before the Senate Budget Committee (http://fraser.stlouisfed.org/historicaldocs/statements/download/28176/Burns_19740821.pdf).

September 20, 1974: Burns’ remarks at the Financial Conference on Inflation (http://fraser.stlouisfed.org/historicaldocs/statements/download/29556/Burns_19740920.pdf).

February 3, 1976: Burns’ statement to the Banking, Currency, and Housing Committee (http://fraser.stlouisfed.org/historicaldocs/statements/download/29131/Burns_19760203.pdf).

February 19, 1976: Burns’ statement before the Joint Economic Committee, Federal Reserve Bulletin, February 1976, pp. 231-236.

July 27, 1976: Burns’ statement before the Banking, Currency and Housing Committee, House of Representatives, Federal Reserve Bulletin, August 1976, pp. 668-674.

February 3, 1977: Burns' statement before the Banking, Finance and Urban Affairs Committee, House of Representatives, Federal Reserve Bulletin, February 1977, pp. 119-124.

February 23, 1977: Burns' statement before the Joint Economic Committee, Federal Reserve Bulletin, March 1977, pp. 222-227.

March 2, 1977: Burns’ statement before the Budget Committee, House of Representatives, Federal Reserve Bulletin, March 1977, pp. 227-233. 
March 22, 1977: Burns' statement before the Budget Committee, U.S. Senate, Federal Reserve Bulletin, April 1977, pp. 358-362.

May 3, 1977: Burns' statement before the Banking, Housing and Urban Affairs

Committee, U.S. Senate, Federal Reserve Bulletin, May 1977, pp. 463-468.

February 28, 1978: “Transcript, Federal Open Market Committee Meeting, February 28, 1978." (www.federalreserve.gov).

\section{B2. Newspaper articles cited}

“Britain’s Economy Stalled,” Kansas City Star, August 26, 1970, page 2B.

Clifford German, "British Inflation Worst of the OECD Nations,” Daily Telegraph (London), November 11, 1970, page 17.

Associated Press, "Signs Pointing Up for U.S. Economy, Budget Chief Says," Omaha World-Herald, February 14, 1971, page 25A.

"Schultze: Inflation Pressures Are Greater Than Expected," Daily News (New York), March 31, 1978, page 32.

Clyde H. Farnsworth, "High Interest Rates: A Federal Reserve Inoculation to Cure the Inflation Disease?,” New York Times, July 4, 1978, page 32. 


\section{References}

Ackley, Gardner (1966). “The Contribution of Guidelines.” In G.P. Shultz and R.Z.

Aliber (eds.), Guidelines: Informal Controls and the Market Place. Chicago: University of Chicago Press. 67-78.

Agriculture and Forestry Committee, U.S. Senate (1975). Russian Grain Sales:

Hearings. Washington, DC: U.S. Government Printing Office.

Banking, Currency and Housing Committee, House of Representatives (1975). Federal Reserve Consultations with Congress on the Conduct of Monetary Policy Pursuant to House Concurrent Resolution 133: Hearings, July 22, 23, and 24, 1975. Washington, DC: U.S. Government Printing Office.

Banking, Currency and Housing Committee, House of Representatives (1976). Federal Reserve Consultations with Congress on the Conduct of Monetary Policy Pursuant to House Concurrent Resolution 133: Hearings July 27 and 28, 1976. Washington, DC: U.S. Government Printing Office.

Banking, Finance and Urban Affairs Committee, House of Representatives (1977a). Federal Reserve Reform Act of 1977: Hearings. Washington, DC: U.S. Government Printing Office.

Banking, Finance and Urban Affairs Committee, House of Representatives (1977b). Conduct of Monetary Policy: Hearings. Washington, DC: U.S. Government Printing Office.

Banking, Housing and Urban Affairs Committee, U.S. Senate (1975). Second Meeting on the Conduct of Monetary Policy: Hearings. Washington, DC: U.S. Government Printing Office.

Banking, Housing and Urban Affairs Committee, U.S. Senate (1977). Fifth Meeting on the Conduct of Monetary Policy: Hearings. Washington, DC: U.S. Government Printing Office. 
Baumol, William J., and Alan S. Blinder (1982). Economics: Principles and PolicySecond Edition. New York: Harcourt Brace Jovanovich.

Benati, Luca (2004). "Evolving Post-World War II U.K. Economic Performance,” Journal of Money, Credit, and Banking, Vol. 36(4), 691-717.

Bernanke, Ben S., Thomas Laubach, Frederic S. Mishkin, and Adam S. Posen (1999). Inflation Targeting: Lessons from the International Experience. Princeton: Princeton University Press.

Beyer, Andreas, Vítor Gaspar, Christina Gerberding, and Otmar Issing (2009). “Opting out of the Great Inflation: German Monetary Policy after the Breakdown of Bretton Woods.” ECB Working Paper No. 1020.

Blinder, Alan S. (1979). “What's 'New' and What's 'Keynesian' in the 'New Cambridge’ Keynesianism?,” Carnegie-Rochester Conference Series on Public Policy, Vol. 9(1), 67-85.

Board of Governors, Federal Reserve System (1970). "Inflation in Western Europe and Japan,” Federal Reserve Bulletin, October, 743-755.

Bordo, Michael, and Barry Eichengreen (2008). "Bretton Woods and the Great Inflation.” NBER Working Paper No. 14532.

Bordo, Michael D., and David C. Wheelock (2004). "Monetary Policy and Asset Prices: A Look Back at Past U.S. Stock Market Booms,” Federal Reserve Bank of St. Louis Review, Vol. 86(6), 19-44.

Budget Committee, House of Representatives (1975). Second Budget Resolution, Fiscal Year 1976: Hearings. Washington, DC: U.S. Government Printing Office.

Budget Committee, U.S. Senate (1975a). The 1976 First Concurrent Resolution on the Budget: Hearings, Volume II. Washington, DC: U.S. Government Printing Office.

Budget Committee, U.S. Senate (1975b). Second Concurrent Resolution on the Budget: Hearings, Volume I. Washington, DC: U.S. Government Printing Office. 
Budget Committee, U.S. Senate (1976). First Concurrent Resolution on the BudgetFiscal Year 1977: Hearings, Volume V. Washington, DC: U.S. Government Printing Office.

Burns, Arthur F. (1951). "Mitchell on What Happens During Business Cycles.” In W.C. Mitchell (ed.), What Happens During Business Cycles: A Progress Report. New York: National Bureau of Economic Research. vii-xi. Reprinted in Arthur F. Burns, The Frontiers of Economic Knowledge. Princeton: Princeton University Press, 1954. 187-198.

Burns, Arthur F. (1978). Reflections of an Economic Policy Maker-Speeches and Congressional Statements: 1969-1978. Washington, DC: American Enterprise Institute.

Cairncross, Alec (1992). The British Economy Since 1945: Economic Policy and Performance, 1945-1990. Oxford: Basil Blackwell.

Cecchetti, Stephen G., Peter Hooper, Bruce C. Kasman, Kermit L. Schoenholtz, and Mark W. Watson (2007). "Understanding the Evolving Inflation Process.” Report for 2007 Meeting of U.S. Monetary Policy Forum, March.

Chari, V.V., Lawrence J. Christiano, and Martin Eichenbaum (1998). "Expectation Traps and Discretion,” Journal of Economic Theory, Vol. 81(2), 462-492.

Christiano, Lawrence J., and Christopher Gust (2000). "The Expectations Trap

Hypothesis," Federal Reserve Bank of Chicago Economic Perspectives, Vol. 24(2), 21-39.

Cochrane, John, (1998). “A Frictionless View of U.S. Inflation,” NBER Macroeconomics Annual, Vol. 13(1), 323-384.

Committee on the Budget, U.S. Senate (1974). The Federal Budget and Inflation: Hearings. Washington, DC: Government Printing Office.

Darby, Michael R., and James R. Lothian (1983). The International Transmission of Inflation. Chicago: University of Chicago Press. 
DeLong, J. Bradford (1997). “America’s Peacetime Inflation: The 1970s.” In C.D. Romer and D.H. Romer (eds.), Reducing Inflation: Motivation and Strategy. Chicago: University of Chicago Press. 247-276.

DiCecio, Riccardo, and Edward Nelson (2007). “An Estimated DSGE Model for the United Kingdom,” Federal Reserve Bank of St. Louis Review, Vol. 89(4), 215-231.

Erceg, Christopher J., Dale W. Henderson, and Andrew T. Levin (2000). “Optimal Monetary Policy with Staggered Wage and Price Contracts,” Journal of Monetary Economics, Vol. 46(2), 281-313.

Friedman, Milton (1972). “Have Monetary Policies Failed?,” American Economic Review (Papers and Proceedings), Vol. 62(2), 11-18.

Friedman, Milton (1979a). “Hooray for Margaret Thatcher,” Newsweek, July 9, p. 56.

Friedman, Milton (1979b). “Correspondence: A Debate on Britain’s Economic Policy,” Director, December, 34-36.

Friedman, Milton, and Anna J. Schwartz (1963). A Monetary History of the United States, 1867-1960. Princeton, N.J.: Princeton University Press.

Friedman, Milton, and Anna J. Schwartz (1982). Monetary Trends in the United States and the United Kingdom: Their Relation to Income, Prices, and Interest Rates, 1867-1975. Chicago: University of Chicago Press.

Gorodnichenko, Yuriy, and Matthew D. Shapiro (2007). “Monetary Policy When Potential Output Is Uncertain: Understanding the Growth Gamble of the 1990s,” Journal of Monetary Economics, Vol. 54(4), 1132-1162.

Hamilton, James D. (1994). Time Series Analysis. Princeton, N.J.: Princeton University Press.

Harrison, Richard, and Ozlem Oomen (2008). "Evaluating and Estimating a DSGE Model for the United Kingdom.” Manuscript, Bank of England. 
Hetzel, Robert L. (1998). “Arthur Burns and Inflation,” Federal Reserve Bank of Richmond Economic Quarterly, Vol. 84(1), 21-44.

Joint Economic Committee (1965). January 1965 Economic Report of the President: Hearings, Part 1. Washington, DC: U.S. Government Printing Office.

Joint Economic Committee (1966). January 1965 Economic Report of the President: Hearings, Part 2. Washington, DC: U.S. Government Printing Office.

Joint Economic Committee (1967). The 1967 Economic Report of the President: Hearings, Part 2. Washington, DC: U.S. Government Printing Office.

Joint Economic Committee (1969). The 1969 Economic Report of the President: Hearings, Part 2. Washington, DC: U.S. Government Printing Office.

Joint Economic Committee (1974). The 1974 Economic Report of the President: Hearings. Washington, DC: U.S. Government Printing Office.

Joint Economic Committee (1975). Midyear Review of the Economic Situation and Outlook: Hearings. Washington, DC: U.S. Government Printing Office.

Laidler, David (1979). “Book Review: The Political Economy of Inflation,” Journal of Political Economy, Vol. 87(4), 896-901.

Lawson, Nigel (1992). The View from No. 11. London: Bantam.

Levin, Andrew T., and John B. Taylor (2008). "Falling Behind the Curve: A Positive Analysis of Stop-Start Monetary Policy and the Great Inflation.” Paper presented at NBER Conference on the Great Inflation, September.

Li, Huiyu, and Hikaru Saijo (2008). "Why Did Aggregate Volatilities Decline in the U.S., U.K. and Japan?” Manuscript, University of Tokyo.

Lombra, Raymond E. (1980). "Reflections on Burns' Reflections,” Journal of Money, Credit and Banking, Vol. 12(1), 94-105. 
McCallum, Bennett T. (1989). Monetary Economics: Theory and Policy. New York: Macmillan.

McCallum, Bennett T. (1995). “Two Fallacies Concerning Central-Bank Independence,” American Economic Review (Papers and Proceedings), Vol. 85(2), 207-211.

Meltzer, Allan H. (2003). A History of the Federal Reserve, Volume 1. Chicago: University of Chicago Press.

Nelson, Edward (2005). “The Great Inflation of the Seventies: What Really Happened?,” Advances in Macroeconomics 3, Article 3.

Nelson, Edward (2008). “An Overhaul of Doctrine: The Underpinning of U.K. Inflation Targeting.” Working Paper, Federal Reserve Bank of St. Louis, August; Economic Journal, forthcoming. http://research.stlouisfed.org/wp/more/2007-026/

Nelson, Edward, and Kalin Nikolov (2004). "Monetary Policy and Stagflation in the U.K.,” Journal of Money, Credit, and Banking, Vol. 36(3), 293-318.

Orphanides, Athanasios (2003). “The Quest for Prosperity without Inflation,” Journal of Monetary Economics, Vol. 50(3), 633-663.

Ramey, Valerie (1993). “How Important Is the Credit Channel in the Transmission of Monetary Policy?,” Carnegie-Rochester Conference Series on Public Policy, Vol. 39(1), $1-45$.

Robbins, Lionel (1973). “A Crisis of Intellectual Error,” Financial Times, December 14, p. 17.

Romer, Christina D. (2005). “Commentary: Origins of the Great Inflation,” Federal Reserve Bank of St. Louis Review, Vol. 87(2), 177-185.

Romer, Christina D. (2007). “Macroeconomic Policy in the 1960s: The Causes and Consequences of a Mistaken Revolution.” Lecture, Economic History Association Annual Meeting, September. 
Romer, Christina D., and David H. Romer (2002). "The Evolution of Economic Understanding and Postwar Stabilization Policy.” In Rethinking Stabilization Policy. Kansas City, MO: Federal Reserve Bank of Kansas City. 11-78.

Romer, Christina D., and David H. Romer (2004). "Choosing the Federal Reserve Chair: Lessons from History,” Journal of Economic Perspectives, Vol. 18(1), 129-162.

Samuelson, Paul A. (1961). “The American Economy on the Move,” Financial Times, August 3, pp. 8 and 14.

Samuelson, Paul A. (1968). “Theoretical Problems.” In On Incomes Policy: Papers and Proceedings from a Conference in Honour of Erik Lundberg. Industrial Council for Social and Economic Studies. 58-62.

Samuelson, Paul A. (1969). "Lessons of the 1960s,” Newsweek, July 14, p. 79.

Samuelson, Paul A. (1970). “Price Controls,” Newsweek, December 28, p. 57.

Samuelson, Paul A., and Robert M. Solow (1960). “Analytical Aspects of Anti-Inflation Policy,” American Economic Review (Papers and Proceedings), Vol. 50(2), 177-194.

Sargent, Thomas J. (1999). The Conquest of American Inflation. Princeton: Princeton University Press.

Smets, Frank, and Rafael Wouters (2007). "Shocks and Frictions in U.S. Business Cycles: A Bayesian DSGE Approach,” American Economic Review, Vol. 97(3), 586-606.

Solow, Robert M. (1966). “Comments.” In G.P. Shultz and R.Z. Aliber (eds.), Guidelines: Informal Controls and the Market Place. Chicago: University of Chicago Press. 62-66.

Solow, Robert M. (1968). "Recent Controversy on the Theory of Inflation: An Eclectic View.” In S.W. Rousseas (ed.), Inflation: Its Causes, Consequences and Control: A Symposium. New York: New York University. 1-17. 
Solow, Robert M. (1969). Price Expectations and the Behavior of the Price Level. Manchester, U.K.: Manchester University Press.

Taylor, John B. (1979). "Estimation and Control of a Macroeconomic Model with Rational Expectations,” Econometrica 47, 1267-1286.

Taylor, John B. (1986). “Reply.” In R.J. Gordon (ed.) The American Business Cycle: Continuity and Change. Chicago: University of Chicago Press. 672-677.

Taylor, John B. (1992). “The Great Inflation, the Great Disinflation, and Policies for Future Price Stability.” In A. Blundell-Wignall (ed.), Inflation, Disinflation and Monetary Policy. Sydney: Ambassador Press. 9-31.

Taylor, John B. (1997). “America’s Peacetime Inflation: The 1970s: Comment.” In C.D. Romer and D.H. Romer (eds.), Reducing Inflation: Motivation and Strategy. Chicago: University of Chicago Press. 276-280. 